\title{
Syysvehnän viljelystä ja sen vaikutuksesta rikkaruohoihin Suomessa
}

\author{
MIKKO RAATIKAINEN JA TERTTU RAATIKAINEN \\ Jyväskylän yliopisto, bioliginen laitos, Yliopistonkatu 9, 40100 Jyväskylä 10
}

\author{
Survey on cultivation of winter wheat and its effect on weeds in Finland \\ Mikko Raatikainen ja Terttu Raatikainen \\ Department of Biology, University of Jyväskylä, \\ Yliopistonkatu 9, 40100 Jyväskylä 10, Finland
}

\begin{abstract}
In Finland, winter wheat is grown in southwestern parts of the country. Long and severe winter prevents the growing elsewhere, while unfavourable weather conditions sometimes limit the planting even in the South.

A survey on winter wheat cultivation and its effects on weeds was carried out in Finland during the years $1972-1974$ on 215 winter wheat fields, chosen by random sampling method. The area of the fields was $4.03 \mathrm{~km}^{2}$ or 0.8 per cent of the total winter wheat cultivation area in Finland.

The characteristics of the winter wheat fields and the methods of estabilishing and managing the winter wheat were investigated in the survey.

The number of vascular plant species found on the winter wheat fields was 130 . The frequency percentage of all species was determined. The average weed number on the fields was $257 / \mathrm{m}^{2}$. The number of plants or shoots of alla taxa/ $\mathrm{m}^{2}$ was determined. Winter annuals Viola arvensis, Matricaria (incl. Tripleurospermum) spp., Stellaria media, Lapsana communis and Myosotis arvensis, summer annuals Galeopsis spp., Chenopodium album, Erysimum cheiranthoides, Polygonum aviculare, Myosurus minimus, Gnaphalium uliginosum and Polygonum convolvulus, and perennials Agropyron repens, Phleum pratense and Poa trivialis had the highest density.

The cover percentage of cereal, the number of herbicidal treatments, soil type, sowing time, the moisture conditions of soil, previous crop, the age of the cultivated field, the distance of the field from the farm building, the number of combine harvestings, and many other factors influenced either directly the density of the weeds or proved density indicators.
\end{abstract}

\section{Johdanto}

Tämä tutkimus muodostaa kolmannen osan Maatalouden tutkimuskeskuksen kasvinviljelylaitoksen toimesta v. 1969 aloitetusta syysviljojen rikkakasvitutkimuksesta. Aikaisemmin ilmestyneissä osatutkimuksissa on käsitelty syysviljojen rikkaruoholajit, niiden yleisyys ja yksilötiheys (M. RAATI-

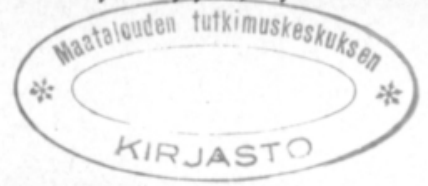


KAINEN et al. 1979) ja syysrukiin viljelytavat ja niiden vaikutukset rikkaruohojen yksilötiheyteen (M. RAATIKAINEN ja T. RAATIKAINEN 1979). Tässä osassa on tarkoitus selvittää v. 1972-1974 viljellyt syysvehnälajikkeet, syysvehnän viljelytekniikka, syysvehnäpeltojen rikkaruoholajit, niiden yleisyys ja yksilötiheys sekä eräiden tekijöiden vaikutukset tiheyteen. Samalla tarkastellaan, miten viljelijät noudattavat oppaissa annettuja ohjeita.

Syysvehnälajikkeiden viljelyaloista on tietoja lajikkeiden viljelykauden alusta eli vuodesta 1922 alkaen, jolloin Tammiston sukkulavehnä laskettiin kauppaan. Käytetystä viljelytekniikasta on hyvin niukasti kvantitatiivisia tietoja. Kvalitatiivisia tietoja sen sijaan on hajallaan monissa artikkeleissa. Syysvehnän rikkaruohoista ei ole aikaisemmin julkaistu Suomesta selvityksiä, mutta torjunta-aineiden tarkastuskokeista on saatu tietoja koepaikkojen lajistosta. Näistä kokeista tehtyjä kasvilajistotietoja ei kuitenkaan ole julkaistu ja niistä on merkitty muistiin yleensä vain runsaimpina esiintyneet lajit (esim. MATIKAINEN ja PIETILÄINEN 1966).

\section{Tutkimusalueet ja menetelmät}

Esitutkimus tehtiin v. 1969 Paimiossa, Laihialla ja Itä-Suomessa. Tällöin selvitettiin kysely-, haastattelu- ja havainnointitutkimuksessa käytettävän lomakkeen sisältö, lohkolta tarvittavien osanäytteiden määrä, osanäytealojen peittämistapa rikkaruohoruiskutuksen ajaksi ja tutkimusalueet. Tutkimusalueet ja niiltä tutkittujen lohkojen märä käy ilmi taulukosta 1 ja kuvasta 1 .

Taulukko 1. Syysvehnän tutkimusalueet ja niillä tutkittujen lohkojen määrät.

Table 1. Winter wheat study areas and the number of winter wheat fields investigated.

\begin{tabular}{|c|c|c|c|}
\hline Vuosi & No. & Tutkimusalue & $\begin{array}{c}\text { Tutkittujen lohkojen } \\
\text { lukumäärä } \\
\text { Number of investigated } \\
\text { winter wheat fields }\end{array}$ \\
\hline \multirow[t]{5}{*}{1972} & 1 & Perniö & 24 \\
\hline & 2 & Lapinjärvi & 23 \\
\hline & 3 & Alastaro & 15 \\
\hline & 4 & Luvia-Nakkila & 7 \\
\hline & 6 & Siilinjärvi-Lapinlahti & 1 \\
\hline \multirow[t]{4}{*}{1973} & 7 & Tuusula & 21 \\
\hline & 8 & Kuusjoki & 26 \\
\hline & 9 & Sauvo & 19 \\
\hline & 10 & Juupajoki-Orivesi & 20 \\
\hline \multirow[t]{5}{*}{1974} & 13 & Kirkkonummi & 13 \\
\hline & 14 & Mellilä & 4 \\
\hline & 15 & Parainen & 27 \\
\hline & 16 & Kalvola-Hattula & 12 \\
\hline & 18 & Oulainen-Haapavesi-Pulkkila & 3 \\
\hline \multicolumn{3}{|c|}{ Yhteensä, Total } & 215 \\
\hline
\end{tabular}




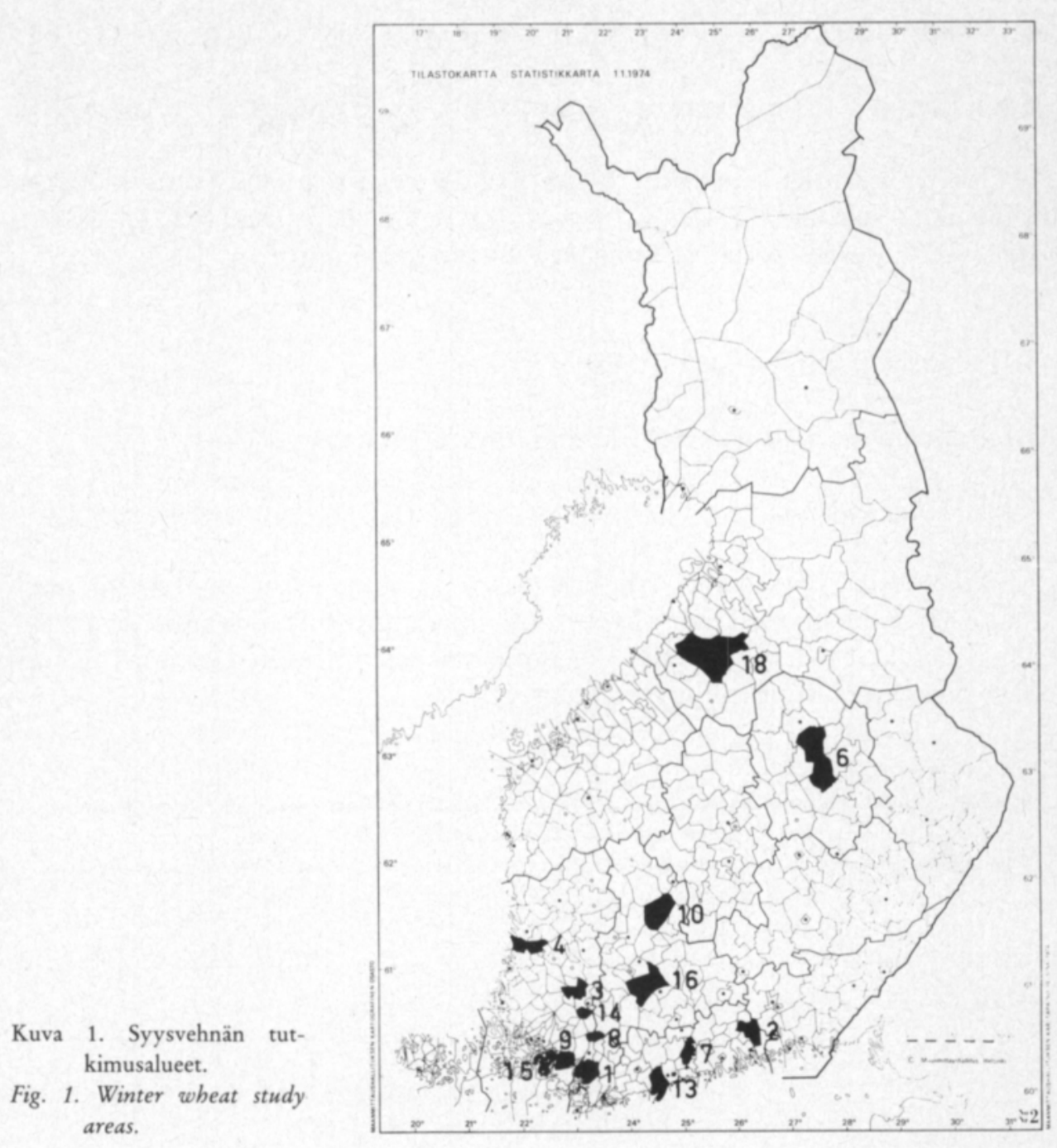

Kaikkiaan tutkittiin 215 syysviljalohkoa. Lohkoksi märiteltiin se syysvehnäpellon osa, joka oli kylvetty saman viljelykasvin jälkeen ja joka oli maalajiltaan yhtenäinen. Joka lohkolta poimittiin satunnaisotannalla neljä $0.25 \mathrm{~m}^{2}$ :n osanäytealaa, joiden rikkakasviyksilömäärät tai versomäärät laskettiin lajeittain tai suvuttain 1.-18. kesäkuuta vuosina 1972-1974. Lisäksi joka lohkolta merkittiin muistiin kaikki lohkolta tavatut putkilokasvilajit. Tarkka selostus menetelmistä on julkaistu aikaisemmin (M. RAATIKAINEN et al. 1979). Muutamissa tapauksissa lohkolta ei saatu kaikkia tietoja. Mm. tutkimusalueelta 1 puuttuvat tiedot taksoneiden tiheydestä. Täydelliset tiedot on aina kuitenkin vähintään 210 lohkolta, mikäli ei toisin mainita. Tutkittu syysvehnäala oli 403 ha, mikä oli 0,8 \% maamme keskimääräisestä vuosittaisesta syysvehnäalasta 52000 ha:sta kyseisenä kautena.

Matemaattisina menetelminä käytettiin tässä osajulkaisussa pienimmän neliösumman menetelmää (HARVEY 1966) ja regressioanalyysiä (DRAPER ja SMITH 1966). Tilastollinen merkitsevyys ilmaistaan seuraavasti: 
${ }^{x x x}=P<0.001,{ }^{x x}=P<0.01 j a^{x}=P<0.05$

Taulukoihin 5-18 on merkitty vain ne lajit, joiden määrissä oli tilastolliset erot.

Kasvinimistönä käytetään LIDin (1963) nimistöä samoin poikkeuksin kuin aikaisemminkin (MUKULA et al. 1969, M. RAATIKAINEN ja T. RAATIKAINEN 1975, 1979). Täten vertailu on lukijalle helpompi.

\section{Tulokset ja niiden tarkastelu}

3.1 Vehnänviljelytilan ja vehnälohkon ominaisuudet

\subsubsection{Tilan peltoala}

Tilat joilla syysvehnää viljeltiin olivat keskimääräistä suurempia (taulukko 2). Vehnänviljelytilat olivat rukiinviljelytilojakin suurempia. Syysvehnän viljelyalueella syysvehnän viljelytilat olivat kuitenkin keskimäärin hieman pienempiä kuin rukiinviljelytilat.

Taulukko 2. Syysvehnää viljelevien tilojen ja syysvehnälohkojen ominaisuuksia sekä syysvehnän perustamista, hoitoa ja suojaviljana käyttöä selvittäviä tietoja.

Table 2. Characteristics of farms and winter wheat fields investigated and the methods of cultivating.

Tilan peltoala, ha - Farm arable area, ha

$1-10$

11-25

26-

Lohkon ikä peltona, vuotta

Age of cultivated field, years

$$
\text { 1-89 }
$$$$
\text { 90-119 }
$$

120

Lohkon pinta-ala, ha - Area of field, ha

$0.1-1.0$

$1.1-2.0$

$2.1-3.0$

$3.1-4.0$

4.1-20.5

Lohkon etäisyys talouskeskuksesta, $m$

Distance of field from farmstead, $m$

$-199$

200-799

800

Maalaji - Soil type

Karkeat kivennäismaat ja hiesut

Coarse mineral soils and silts
Savimaat - Clay soils

Eloperäiset maat - Organic soils

Maaperän kosteus - Moisture conditions of soil

Poutiva - Dry

Keskikertainen - Medium

Veden vaivaama - Wet

Ojitus - Type of drainage

Avo-ojitus - Open drainage

Sala-ojitus - Underdrainage

Ojittamaton - Undrained

Leikkuupuintien määrä 10 viime vuoden aikana

Combine harvesting during 10 years

Rikkaruohoruiskutusten määrä $10 \mathrm{v}$ :n aikana

Herbicidal treatments during 10 years 
Esikasvi - Previous crop

Kevätvilja-Spring cereal

Syysvilja - Winter cereal

Nurmi-Ley

Muut kasvit - Other plants

Viljelykasvi kaksi vuotta sitten

Crop two years ago

Kevätvilja - Spring cereal

Syysvilja - Winter cereal

Nurmi-Ley

Muut-Other plants

Viljelykasvi kolme vuotta sitten - Crop three years ago

Kevätvilja - Spring cereal

Syysvilja - Winter cereal

Vilja-Cereal

Nurmi - Ley

Muut-Other plants

Vljelykasvi neljä vuotta sitten - Crop four years ago

Kevätvilja - Spring cereal

Syysvilja - Winter cereal

Vilja-Cereal

Nurmi-Ley

Muut-Other plants

Nurmenaolovuosien määrä välittömästi ennen esikasvia -

Years as ley before the previous crop

$$
\begin{aligned}
& 0 \\
& 1 \\
& 2 \\
& 3
\end{aligned}
$$

1

2

Karjanlannan määrä syksyllä, t/ha

Farmyard manure in autumn, tons/ha

$$
\begin{aligned}
& 0 \\
& 1-20 \\
& 21-40 \\
& 41-60 \\
& 61-80 \\
& 81-
\end{aligned}
$$

Typpimäärä väkilannoitteena syksyllä, kg/ha Nitrogen fertilization in autumn, $\mathrm{kg} / \mathrm{ha}$

$$
\begin{aligned}
& 0 \\
& 1-50 \\
& 51-75 \\
& 76-
\end{aligned}
$$

Fosforimäärä väkilannoitteena syksyllä, kg/ha Phosphorus fertilization in autumn, $\mathrm{kg} / \mathrm{ha}$

$$
\begin{aligned}
& 0 \\
& 1-30 \\
& 31-60 \\
& 61-
\end{aligned}
$$

Kaliummäärä väkilannoitteena syksyllä, $\mathrm{kg} / \mathrm{ha}$

Potassium fertilization in autumn, $\mathrm{kg} / \mathrm{ha}$ 0

$1-50$

$51-75$

76

Lajike - Winter wheat cultivar

Vakka

Elo 12

Nisu 10

Linna 9

Varma

Jyvä

Peittaus - Seed dressing product

Täyssato, kuivapeittaus- tai nestepeittausvalmiste $\quad 54$

Ceresan,

Aagrano,

Benlate

Tehopeittausjauhe

Panogen M 12

Kylvösiemenmäärä, $\mathrm{kg} / \mathrm{ha}-$ Seed rate, $\mathrm{kg} / \mathrm{ha}$

$160-180$

$190-220$

$230-260$

$270-300$

$310-330$

Kylvöaika - Sowing time

9.VIII-28.VIII

29.VIII- 7.IX

8.IX $-8 . \mathrm{X}$

Talvilannoitus - Fertilization in winter

Typen määrä keväällä, kg/ha

Nitrogen fertilization in spring, $\mathrm{kg} / \mathrm{ha}$ 0

$1-50$

51-75

$76-$

Rikkaruohokäsittely - Herbicidal treatment Traktoriruiskutus - tractor spraying

Reppuruiskutus - knapsack spraying

Ruiskuttamaton - Untreated

Rikkaruohojen ruiskutusaika

Time of herbicidal treatment

$$
\text { 1.-10.V }
$$

11. $-15 . \mathrm{V}$

16. $-20 . \mathrm{V}$

21. $-25 . \mathrm{V}$

26. $-30 . \mathrm{V}$

31.V- 


\begin{tabular}{|c|c|c|c|}
\hline Rikkaruohontorjunta-aine - Herbicide used & & Tuntematon - unknown & 1 \\
\hline $\mathrm{MCPA}-M C P A$ & 7 & & \\
\hline Mekopropi-Mecoprop & 10 & Rikkaruohoruiskutuksessa käytetty vesimäärä, 1/ha & \\
\hline MCPA-, mekoproppi- ja diklorproppi-seokset & & Amount of water, $\mathrm{l} / \mathrm{ha}$, used in berbicidal treatment & \\
\hline Mixtures with MCPA, mecoprop and dichlorprop & 15 & $170-224$ & 55 \\
\hline 2,4-D-seokset - Mixtures with 2,4-D & 18 & $225-274$ & 25 \\
\hline Dikamba- ja TBA-seokset - Mixtures with & & $275-324$ & 14 \\
\hline dicamba and $T B A$ & 46 & $325-374$ & 2 \\
\hline Dinosebi- ja ioksiniiliseokset & & $375-600$ & 4 \\
\hline Mixtures with dinoseb and ioxynil & 3 & & \\
\hline
\end{tabular}

\subsubsection{Lobkon ikä peltona}

Syysvehnällä olleiden lohkojen ikää peltona ei saatu tarkasti määritetyksi varsinkaan vanhimmilla viljelyksillä. Noin kolmannes syysvehnällä olleista pelloista oli kuitenkin raivattu ennen peltoheinän viljelyn alkua, ja kolmannes niistä raivattiin kautena, jolloin nurmeksi kylvettyjen peltojen tilalle raivattiin uutta peltoa etenkin niityistä (taulukko 2). Syysvehnällä olleet pellot olivat vanhempia, ravinteisempia ja vähemmän happamia kuin rukiilla olleet pellot.

\subsubsection{Lobkon pinta-ala}

Syysvehnälohkojen pinta-alat vaihtelivat 0.1 ha:sta, joka oli pienin tutkittava lohkon koko, 20.5 ha:iin. Keskimääräinen koko oli 1.9 ha. Pieniä lohkoja oli eniten (taulukko 2), ja 63 \% lohkojen määärästä oli alle keskiarvon. Pieniä lohkoja oli etenkin syysvehnän viljelyalueen pohjoisosassa, ja eteläosan kallioisilla saaristoalueilla. Suuria lohkoja oli eniten Lounais-Suomen lakeuksilla olevilla savikoilla. Syysvehnälohkojen keskikoko oli 0.6 ha suurempi kuin ruislohkojen. Tämä aiheutui siitä, että Väli-Suomen alueen ruislohkot olivat pieniä. Lounais-Suomessa syysvehnä- ja ruislohkot olivat jokseenkin samansuuruiset.

\subsubsection{Lohkon etäisyys talouskeskuksesta}

Syysviljalohkon etäisyys talouskeskuksesta mitattiin viljelystietä pitkin lohkon lähimpään reunaan. Lohkoista oli yli puolet alle $0.5 \mathrm{~km}: \mathrm{n}$ etäisyydellä talouskeskuksesta (taulukko 2), ja ne olivat keskimäärin lähempänä kuin ruislohkot. Syysvehnän viljelyalueellakin syysvehnää viljeltiin selvästi lähempänä talouskeskusta kuin ruista. 


\subsubsection{Maalaji}

Syysvehnälohkoista oli $3 / 4$ savimaalla, jota on suositeltu kaikissa oppaissa parhaana maalajina syysvehnälle (taulukko 2). Karkealla kivennäismaalla ja hiesulla oli kuitenkin noin viidennes lohkoista, mutta eloperäisellä maalla vain $5 \%$. Eri syysvehnälajikkeiden onkin selvästi todettu kärsineen talvivaurioista vähemmän savi- kuin hietamailla, ja hehtaarisadotkin ovat olleet savimailla selvästi suuremmat ja laadultaan paremmat kuin hietamailla (TALVITIE ja KONSALA 1971, MUKULA ja RANTANEN 1976). Kasvualustan multavuuden on todettu heikentävän syysvehnän talvehtimista ja satoa (esim. VALLE 1962). Keveillä mailla etenkin talvituhosienien ja rousteen aiheuttamat vauriot ovat merkittäviä (JAMALAINEN 1962, 1964, MUKULA ja RANTANEN 1976).

Syysvehnä sijoitettiin selvästi useammin savimaille kuin ruis, jota viljeltiin ohjeiden mukaisesti etupäässä karkeilla kivennäismailla.

\subsubsection{Maaperän kosteus}

Poutivuudella tarkoitetaan tässä kasvien kärsimää veden puutetta viljelijän esittämän käsityksen mukaan. Syysvehnäviljelykset olivat keskimäärin poutivampia kuin ruisviljelykset (taulukko 2). Tämä ei kuitenkaan aiheutunut siitä, että vehnää olisi pyritty viljelemään poutivammilla paikoilla kuin ruista, vaan siitä että syysvehnän viljelyalueella oli paljon poutivia maita, joilla syysvehnää melko hyvin poutaa kestävänä lajina jouduttiin viljelemään. Syysvehnän viljelyalueella viljellään myös ruista kosteusominaisuuksiltaan samanlaisella alustalla, koska ruiskin on melko kestävä poutaa vastaan. Kasvukauden aikainen kuivuus ei olekaan syysvehnän viljelyssä vakava riskitekijä, joskin se saattaa toisinaan kylvön myöhästyessä ja juuriston jäätyä heikoksi estää sadonmuodostusta (KÖYLIJÄRVI 1975, MUKULA ja RANTANEN 1976). Syysvehnän viljelyä voitaisiin ilmeisesti siirtää yhä useammin poutiville maille, mikäli tähän on tarvetta.

\subsubsection{Ojitus}

Syysvehnän viljely oli keskittynyt selvemmin salaojitetuille maille kuin rukiin viljely (taulukko 2 ), mikä on luonnollista koska syysvehnän viljelyalueen pelloista oli paljon suurempi osa salaojitettuja kuin rukiin viljelyalueen pelloista. Tästä on monia etuja. Mm. salaojitetut maat tulevat huolellisemmin muokattua ja piennaralueita on vähän. Nämä molemmat vähentävät rikkaruohottumista, mikä yleensä on syysvehnän viljelyssä merkittävämpää kuin rukiin viljelyssä, sillä syysvehnä on rikkaruohoja vastaan heikompi kilpailija kuin peittävä ja tiheäkasvuinen ruis. 


\subsubsection{Leikkuиpuimurin käyttö ennen rukiin viljelyä}

Syysvehnää viljelevät tilat olivat usein keskittyneet viljanviljelyyn ja siksi syysvehnälohkoilla oli käytetty viimeisen kymmenen vuoden aikana huomattavasti useammin leikkuupuimuria kuin rukiinviljelytiloilla, joista monet olivat nurmivaltaisia karjatiloja (taulukko 2). Syysvehnän viljelyalueellakin vehnälohkoilla oli käytetty useammin leikkuupuimuria kuin ruislohkoilla. Leikkuupuinti aiheutti peltojen voimakkaan rikkaruohottumisen, ja se vuorostaan herbisidien käytön.

\subsubsection{Rikkaruohoruiskutusten määrä ennen vehnän viljelyä}

Syysvehnän viljelylohkoilla oli tehty 10 viimeksi kuluneen vuoden aikana paljon enemmän rikkaruohoruiskutuksia kuin syysruislohkoilla sekä koko maassa että syysvehnän viljelyalueella (taulukko 2). Ruiskutuskertojen määrä oli lähes samansuuruinen kuin leikkuupuintikertojen määrä, mikä todistaa ettei aivan kaikkia viljalohkoja käsitelty herbisideillä. Syinä lukuisiin käsittelyihin olivat $\mathrm{mm}$. viljelijöiden valistuneisuus, runsas käytettävissä ollut ruiskutusvälineistö ja syysvehnän viljely kevätvilja- ja syysvehnävaltaisessa viljelykierrossa, jolloin ruiskutuksia jouduttiin tekemään usein. Herbisidien käyttö on kuitenkin nuorta, sillä se alkoi 1940-luvun lopulla ja laajeni huomattavasti vasta 1962 aloitetun torjuntakampanjan aikana ja sen jälkeen.

\subsubsection{Esikasvi}

Syysvehnän tavallisin esikasvi oli syysvehnä, mikä osoittaa, että syysvehnää viljeltiin eräillä tiloilla monokulttuurina tai ainakin lähes monokulttuurina sillä vilja oli esikasvina $66 \%$ :ssa tapauksista (taulukko 2). Tällaisesta yksipuolisesta viljelystä on ollut seurauksena $\mathrm{mm}$. tyvitautien yleistyminen ja alentuneet vehnäsadot, mutta muutaman vuoden kuluttua tautisuus on vähentynyt ja sadot tasoittuneet pieneliötoiminnan tasapainottuessa (YLIMÄKI 1975). Nurmea käytettiin rukiin esikasvina useammin kuin syysvehnän, mutta syysvehnän viljelyalueella nurmen käyttö esikasvina oli yhtä yleistä kummallakin kasvilla. Syysvehnää on ensisijaisesti suositeltu perustettavaksi täyskesantoon lähes kaikissa tällä vuosisadalla ilmestyneissä oppaissa. Tätä tapaa noudatettiinkin vuosisadan alkupuolella lähes aina (SAULI 1929). Vaikka sadot ovatkin kesantoon perustetuissa syysvehnissä suurimmat niin taloudellinen tulos on kuitenkin heikko, ja siksi syysvehnä on alettu perustaa lähes aina jonkin aikaisin korjattavan viljelykasvin jälkeen. Tällaisiksi on suositeltu vihantarehu- ja nurmikasveja, aikaista perunaa, aikaista hernettä (SAULI 1929, 1943), syysrypsiä, ohraa (VALLE 1962) ja viime aikoina myös kauraa (LAMPINEN 1976). Ohjeita on noudatettu vain osaksi ja käytännöllisistä syistä syysviljoista on tullut käytetyin esikasvi, vaikka tästä on varoitettu usein (mm. LAMPINEN 1976). Viljelijät ovat ilmeisesti kokemuksesta päätyneet siihen, ettei yksipuolisesta syysviljan viljelystä ole niin suurta 
haittaa esim. kasvitautien osalta kuin mitä maatalousneuvonnassa yleisesti väitetään. Kesantopalkkion turvin vïme aikoina on aikaisempaa suuremmat mahdollisuudet myös kesantoon kylvöön (KÖYLIJÄRVI 1980a).

Lounais-Suomen viljavaltaisissa kasvinvuorotteluissa viljeltiin lohkolla yleisimmin kevät- ja syysviljoja myös $2-4$ vuotta ennen syysvehnän viljelyä. Nurmien lukumäärää kolmena esikasvivaihetta edeltävänä vuonna voidaan käyttää lohkon rikkakasvien yksilötiheyden selittäjänä. Se kuvastaa myös avoviljelykasvien osuutta lohkon viljelykasveina.

\subsection{Syysvehnän perustaminen}

\subsubsection{Peruslannoitus}

Karjanlantaa käytettiin peruslannoituksena vain $12 \%$ :lla syysvehnälohkoista, lähinnä kesantolohkoille ja niillekin sitä annettiin yleensä vähän (taulukko 2). Karjanlantaa suositeltiin aikoinaan (esim. SAULI 1929, 1943) savimaille kesannon jälkeen viljeltävälle syysvehnälle, mutta tästä tavasta on täytynyt luopua koska karjanlantaa ei ole riittävästi saatavissa ja esikasvin jälkeen sitä ei voida yleensä käyttääkään talvivaurioiden takia (SAULI 1943). Karjanlannan käyttö syysvehnän lannoittamiseen oli vähäisempää kuin syysrukiin lannoittamiseen.

Väkilannoitteita annettiin noin $95 \%$ :lle syysvehnälohkoista (taulukko 2), joten niitä annettiin myös sellaisille lohkoille, jotka olivat saaneet osan ravinnetarpeesta karjanlannasta. Väkilannoitteina annetun typen määrä oli kutakuinkin suositusten mukainen (PESSI 1970). Fosforin ja kalin määrät ylittivät suositukset (vrt. PESSI 1970), mikä osoittaa, että viljelijät pyrkivät ottamaan maasta irti mahdollisimman suuren sadon kiinnittämättä tarpeeksi huomiota optimointiin.

Peruslannoituksessa kaikkien annettujen lannoitteiden määrät olivat keskimäärin suurempia kuin rukiille annetut.

\subsubsection{Lajike}

Yleisin syysvehnälajike oli v. 1953 kauppaan laskettu tähkäidännälle erittäin altis, aikainen Vakka, jonka viljely oli keskittynyt lounaisimpaan osaan Suomea (taulukko 2). Seuraavilla sijoilla olivat v. 1963 kauppaan laskettu Elo, v. 1966 kauppaan laskettu Nisu ja v. 1965 kauppaan laskettu Linna, joita viljeltiin muussa osassa Suomea, mutta joista kuitenkin Elon viljely keskittyi etelä- ja kaakkoisosaan ja Nisun luoteisosaan. Tulokset ovat hyvin samanlaiset kuin Valtion viljavaraston selvityksissä, joihin MUKULA ja RANTANEN (1976) perustavat selvityksensä lajikkeiden viljelyssä tapahtuneista muutoksista. V. 1933 kauppaan laskettua Varmaa viljeltiin vielä lounaisimmassa osassa maata suppeammalla alueella kuin siitä ja Kehrästa polveutuvaa Vakkaa. Vakasta polveutuvaa, v. 1965 kauppaan laskettua Jyvää viljeltiin hyvin vähän ja osaksi sekaviljana Nisun kanssa. Tulokset osoittavat, että 
viljelijät kiinnittivät neuvontaan huomiota, ottivat melko nopeasti käyttöön uudet suositellut lajikkeet ja viljelivät yleensä alueelle suositeltuja parhaita lajikkeita (vrt. KÖYLIJÄRVI 1971, TALVITIE ja MARJANEN 1972, TALVITIE ja LALLUKKA 1973a ja b). Uusimpien hyvien lajikkeiden viljelyn olisi kuitenkin tullut yleistyä nopeammin.

\subsubsection{Kylvösiemenen peittaus}

Syysvehnälohkoista vain $6 \%$ :n siemen oli peittaamatta (taulukko 2). Nämä lohkot olivat syysvehnän yleisen viljelyalueen itä- ja pohjoisosassa. Peittaukseen käytettiin yleisimmin siemenlevintäisiä homesieniä torjuvia elohopeapitoisia alkoksialkyyliyhdisteitä, joilla peitattiin $96 \%$ ja loppu $4 \%$ peitattiin lumihomeeseenkin tehoavalla benomyylillä (ks. VANHANEN 1981). Taulukkoon 2 on koottu peittaukseen käytettyjen kauppavalmisteiden osuudet laskettuna siitä lohkomäärästä (179), josta saatiin tiedot peittaukseen käytetystä kauppavalmisteesta. Siitä käy ilmi, että syysviljalohkoista peitattiin Kemiran valmisteilla $54 \%$, Bernerin valmisteilla $26 \%$, Farmoksen valmisteilla $16 \%$ ja Maatalouspalvelun valmisteilla $4 \%$.

Talvituhosienistä Fusarium nivale (Fr.) Ces. ja Typhula ishikariensis Lasch ex Fr. aiheuttivat tavallisimmin vioituksia syysvehnässä (JAMALAINEN $1964,1969)$. Talvituhosienivauriot olivat suurimmat vähän routaantuvilla ja runsaslumisilla paikoilla. Kaikki syysvehnän siemen kannatti peitata JAMALAISEN $(1962,1966)$ mukaan. Nämä ohjeet oli otettu vastaan, mutta elohopeapitoisiin peittausaineisiin kohdistuneen v. 1965 alkaneen kovan kritiikin takia peittaus väheni vuodesta 1966 alkaen ja alkoi yleistyä uudelleen v. 1968 (mm. M. RAATIKAINEN 1970). Peittaus yleistyi tutkimuskautenakin, ja silloin laskettiin käsitellyn noin 58 \% leipävilja-alasta peittausaineilla (MARKKULA 1973, 1974, MARKKULA ja TIITTANEN 1975), mikä syysvehnän osalta oli tämän tutkimuksen mukaan kuitenkin liian alhainen prosenttiluku. Uudentyyppisinä torjunta-aineina kauppaan laskettujen fuberidatsonipitoisen Voronitin ja benomyylipitoisen Benlaten käyttö oli alhainen.

Syysvehnän kylvösiemenen peittaus oli paljon yleisempää kuin syysrukiin (vrt. M. RAATIKAINEN ja T. RAATIKAINEN 1979).

\subsubsection{Kylvösiemenmäärä}

Syysvehnää suositeltiin kylvettäväksi siemenen koosta, kylvöajasta ja maan kasvukunnosta riippuen 160-220 kg/ha (VALLE 1962, KÖYLIJÄRVI 1974) tai $180-200 \mathrm{~kg} / \mathrm{ha}$ (LAMPINEN 1971). Lisäksi itävyys, orastuminen ja puhtaus vaikuttavat siemenmäärään. Tämän tutkimuksen mukaan siementä kylvettiin keskimäärin $246 \mathrm{~kg} / \mathrm{ha}$, mikä on huomattavasti suurempi märä kuin suositus, ja osoittaa, että kylvösiemenen itävyys olisi ollut noin $80 \%$ jos kasvitiheys olisi ollut suunnilleen suositusten mukainen (taulukko 2). Valtion siementarkastuslaitoksen tutkimusten mukaan syysvehnän itävyys oli tutkimuskautena noin $91 \%$ ja peittaus kohotti sitä 1,1 prosenttiyksikköä. Osa 
kylvöistä oli kuitenkin myöhässä ja tällöin siemenmäärän tuli ollakin noin 20 \% normaalia suurempi (KÖYLIJÄRVI 1975).

\subsubsection{Kylvöaika}

Syysvehnää kylvettiin 9.VIII ja 8.X välisenä kautena, ja keskimääräinen kylvöpäivä oli 5.IX (taulukko 2). Kylvöaika oli 11 vuorokautta myöhäisempi kuin rukiin (vrt. M. RAATIKAINEN ja T. RAATIKAINEN 1979). Tämän vuosisadan alkupuolella syysvehnän kylvö tehtiin 9.-21. elokuuta tavallisesti ennen rukiin kylvöä, mutta jo 1920-luvulla syysvehnä neuvottiin kylvämään rukiin kylvön jälkeen, Etelä-Suomessa noin 20. elokuuta (SAULI 1929). V. 1927 aloitetut ja sen jälkeen tehdyt kylvöaikakokeet osoittivat, että syysvehnä tuli kylvää myöhemmin kuin ruis ja kylvöajaksi suositeltiin EteläSuomessa noin 29. elokuuta (SAULI 1943, SIMONEN 1944). Kesantoon kylvettäessä suositeltiin kylvöajaksi syyskuun ensimmäistä viikkoa (VALLE 1962). Noin kolmenkymmenen vuoden aikana tehdyissä kylvöaikakokeissa on todettu, että paras sato saadaan syysvehnästä etenkin paikasta, lajikkeesta ja vuodesta riippuen noin 1.-6. syyskuuta tehdyistä kylvöistä. Pohjoisosissa kylvö tuli tehdä elokuun lopulla, etelässä syyskuun alussa (HONKAVAARA 1958, VALLE 1958, HAKKOLA 1966, YLLÖ 1969, SIMOJOKI 1972, KÖYLIJÄRVI 1974, 1975, MARJANEN 1975, MUKULA ja RANTANEN 1976). Kun kahukärpästä ei esiintynyt tai se olisi torjuttu olisi suurin sato saatu ilmeisesti tätä aikaisemmin tehdyistä kylvöistä. KÖYLIJÄRVI (1980b) ja SIMOJOKI (1980) ovatkin myöhemmin suositelleet aikaisempaa kylvöaikaa. Kylvöajan siirtämisellä syysvehnän hehtaarisato on noussut tällä vuosisadalla monia satoja kiloja, ja jos aina voitaisiin noudattaa ihanteellista kylvöaikaa, niin hehtaarisadon nousu olisi ollut nykyisillä lajikkeilla mitattuna noin $20 \%$. Kylvöajan hajonta oli v. 1972 ja 1973 sateisuuden takia, mutta myös viljelijän ja kuivuudenkin takia liian suuri. Osaksi kylvöaika oli liian myöhäinen, jolloin kylvökeli oli huono eikä syysvehnä ehtinyt sopivalle kehitysvaiheelle talvehtimaan.

\subsection{Hoitotavat}

\subsubsection{Kabukärpästen torjunta}

Kahukärpästen torjuntaan on tällä vuosisadalla kiinnitetty huomiota tehostuneessa neuvonnassa, ja sen ansiosta syysvehnän kylvöaika on sïrtynyt 2-3 viikkoa myöhäisemmäksi ja kahukärpäsen viljelytekninen torjunta on ratkaistu useimpina vuosina. TIITTASEN (1959) selvitysten mukaan kahukärpästen aiheuttama vioitusprosentti oli 15. elokuuta kylvetyissä syysvehnissä $32 \%$, 29. elokuuta kylvetyissä 21 ja 5 . syyskuuta kylvetyissä $4 \%$. Täten kahukärpästen aiheuttama vioitus on alentunut tällä vuosisadalla noin kuudesosaan entisestä ja syysvehnän hehtaarisato on kohonnut useita satoja kiloja/ha. Tämän tutkimuksen aineistossa ei ollut ainuttakaan lohkoa, jolla 
olisi torjuttu kahukärpäsiä kemiallisesti. Aikaisin kylvetyillä syysvehnälohkoilla torjunta olisi kannattanut. Kylvöjä voidaan siirtää aikaisemmaksi kahukärpästen kemiallisen torjunnan lisäämisellä hoitotoimenpiteisiin tai kahukärpäsenkestäviä lakjikkeita jalostamalla ja viljelemällä.

\subsubsection{Talvitubosienten torjunta orasasteella}

Tutkituista syysvehnälohkoista vain yksi alueella 4 sijaitseva oli käsitelty kvintotseeniä sisältävällä Oraansuojalla ja siemenkin oli peitattu elohopeapitoisella peittausaineella. Savimailla oraiden käsittely on tarpeetonta syysvehnän pääviljelyalueella, mutta koska vehnälajikkeittemme talvituhosienien kestävyys oli vähäinen olisi karkeilla kivennäismailla, orgaanisilla mailla, jopa hiesuisilla savimaillakin olleet oraat pitänyt käsitellä fungisideilla. Pohjoisempana paksun ja pitkään säilyvän lumipeitteen alueella käsittely olisi tehtävä lajikkeesta ja elohopeapeittauksesta huolimatta (LINNOMÄKI 1962, JAMALAINEN 1964, 1969, JAMALAINEN ja LINNOMÄKI 1966, SIMOJOKI 1972).

\subsubsection{Talvilannoitus}

1960-luvun loppupuolella alettiin kokeilla typen levitysaikojen, etenkin syys- ja talvilevityksen vaikutusta satoon ja sen laatuun. Osassa kokeita marras-joulukuussa tehdyt levitykset antoivat suurimmat tai lähes suurimmat jyväsadot, mutta valkuaispitoisuus oli alhainen (PESSI 1969, 1970). Tulosten julkaiseminen johti eräillä tiloilla talvilannoituksen kokeiluun, ja tämän tutkimusaineiston mukaan syysvehnälohkoista $0.5 \%$ (taulukko 2 ) ja syysvehnäalasta $0.3 \%$ lannoitettiin talvikautena. Tämä levitysaika ei kuitenkaan yleistynyt tutkimuskautena, koska muiden tutkimustulokset osoittivat kevätlannoituksen parhaaksi (esim. KÖYLIJÄRVI 1972).

\subsubsection{Kevätlannoitus}

Kaikissa tällä vuosisadalla ilmestyneissä oppaissa suositellaan syysvehnälle täydennyslannoitukseksi typpeä, ja $97 \%$ :lle tutkituista lohkoista tällainen lannoitus annettiinkin (taulukko 2). Typpeä annettiin ohjeiden mukaisesti runsaimmin savimailla viljan jälkeen viljeltävälle syysvehnälle, ja lannoitemäärät olivat yleensä viimeisten suositusten mukaiset (vrt. VALLE 1962, PESSI 1970). Viljelijät pyrkivät käyttämään mahdollisimman suuria typpimääriä vaikka osittain laiminlöivätkin muun siihen liittyvän viljelytekniikan. Tästä oli seurauksena sateisina kesinä lakoontuneet kasvustot. Typpi levitettiin yleensä varhain keväällä vaikka valkuaisköyhän syysvehnän proteiinipitoisuuden kohottamiseksi myöhäisempi levitys olisi antanut paremman tuloksen, ja tätä tapaa on suositeltu useissa oppaissa (esim. SIMONEN 1944, VALLE 1962, PESSI 1970). Hinnoittelussa valkuaispitoisuutta ei kuitenkaan otettu huomioon, joten levitys pyrittiin tekemään kannattavimmalla tavalla. 
Myöhäisessä typen levityksessä oli myös riski, että kuivina keväinä typpi ei tullut savimailla kasvien käyttöön rïttävän ajoissa.

Syysvehnälle annetut typpimäärät olivat huomattavasti suuremmat kuin syysrukiille annetut, koska lujakortinen vehnä kestää lakoutumatta suuremman typpilannoituksen kuin ruis.

\subsubsection{Rikkaruohoruiskutus}

Syysvehnän kemiallinen rikkaruohontorjunta tehtiin aina ruiskuttamalla ja lähes yksinomaan traktoriruiskua käyttäen (taulukko 2). Ruiskuttamaton ala jäi paljon pienemmäksi kuin syysruisviljelyksillä (vrt. taulukko 2 ja $\mathrm{M}$. RAATIKAINEN ja T. RAATIKAINEN 1979). Tämä onkin ymmärrettävä, sillä valoa läpäisevämpi, talvikautena usein harventunut ja keväällä ruista myöhemmin kasvunsa aloittava syysvehnä rikkaruohottuu pahemmin kuin ruis, eikä vehnä kykene myöhemminkään tukahduttamaan rikkaruohoja yhtä hyvin kuin ruiskasvusto. Torjunta-aineiden myyntitilastojen mukaan (MARKKULA 1973, 1974, MARKKULA ja TIITTANEN 1975) viljakasvien kokonaispinta-alasta voitiin käsitellä tutkimuskautena $68 \%$ MCPA:lla tai vastaavilla aineilla.

Rikkaruohoruiskutusten ajaksi suositeltiin varhaiskevättä, heti kun maa oli kuivunut koneita kantavaksi ja ilman lämpötila kohonnut torjuntaaineesta riippuen yli $7-10^{\circ} \mathrm{C}$ (MUKULA 1964, M. RAATIKAINEN et al. 1971). Useimmat suorittivatkin käsittelyn oikeana ajankohtana (taulukko 2), mutta osa joko liian myöhään tai sopimattomalla säällä.

Kemiallisen rikkaruohontorjunnan alkuaikoina syysvehnälle suositeltiin aluksi MCPA:ta, sitten 2,4-D:tä ja myöhemmin eräitä muita torjunta-aineita ja seosvalmisteita (esim. LÄHDE et al. 1955, HILLI 1962, MUKULA 1964, M. RAATIKAINEN et al. 1971). Tämä muutos on ollut välttämätön torjuntatuloksen parantamiseksi entisiä torjunta-aineita kestävien lajien osuuden suurentuessa. Viljelijät ovat yleensä seuranneet tilannetta, mutta monet sïrtyivät uusiin aineisiin kuitenkin hitaammin kuin rikkakasvikoostumuksen perusteella olisi pitänyt (taulukko 2).

Rikkaruohontorjunta-aineet sekoitettiin veteen, jota suositeltiin käytettäväksi tavallisesti $200-400 \mathrm{l} / \mathrm{ha}$. Syysvehnälle käytetty vesimäärä vaihteli 170 ja 600 l/ha välillä, ja keskimäärin se oli 240 l/ha (taulukko 2). Ruiskuttajat käyttivät yleisimmin pienintä suositeltua nestemäärää, joka riitti systeemisille aineille. Kosketusherbisideille nestemäärä olisi saanut olla eräissä tapauksissa käytettyä määrää suurempi.

\subsubsection{Korrenvahvistajan käyttö}

Korrenvahvistajan käytöstä kerättiin tiedot vain vuodelta 1974. Tämän aineiston mukaan syysvehnän lakoutumista estettiin $7 \%$ :lla lohkoista ruiskuttamalla kasvustoon yhdessä herbisidien kanssa klormekvattikloridia. Koska syysvehnä ei ole kovin herkkä klormekvatille käytettiin sitä suurimpia 
sallittuja määriä ja joskus ylisuuriakin määriä, mikä lienee heikentänyt taloudellista tulosta ja sadon laatua. Klormekvattikloridin käyttö näytti olleen syysvehnällä harvinaisempaa kuin syysrukiilla. Koetulosten perusteella käyttöä ei suositeltu ainakaan lisäämättä typpilannoitusta (MUKULA ja TEITTINEN 1967, SIMOJOKI 1972)

\subsection{Syysvehnän käyttö suojaviljana}

Syysvehnää on pidetty kuten ruistakin jo melko varhain nurmen suojakasvina, mutta pensovana, varjostavana ja myöhään korjattavana sitä ei pidetty hyvänä suojakasvina (esim. WALLE 1929). V. 1951 syysvehnään perustettiin $1.7 \%$ nurmistamme, ja sillä oli paikallista merkitystä suojakasvina Etelä-Suomessa (PAATELA 1953a). V. 1966-1968 syysvehnä oli vain 1 $\%$ :lla perustettavista nurmista suojakasvina (M. RAATIKAINEN ja T. RAATIKAINEN 1975). PAATELAn (1953a) tutkimukseen perustuen laskettiin, että v. 1951 syysvehnäalasta noin $35 \%$ käytettiin nurmen suojakasvina ja v. 1972 1974 tämän tutkimuksen mukaan enää vain $0.8 \%$. Syysvehnän suhteellinen käyttö nurmen suojakasvina oli lähes yhtä suurta kuin syysrukiin.

\subsection{Rikkaruoholajit, niiden yleisys ja yksilötiheys}

\subsubsection{Lajisto ja lajien yleisyys}

Tutkituilta 215 syysvehnälohkolta tavattiin 130 putkilokasvilajia kun taulukossa 3 mainittujen lajien lisäksi myös tekstissä mainitut lajit otetaan huomioon. Lajimäärä oli pienempi kuin heinänurmista vastaavalta lohkomäärältä löydetty lajimäärä, ja kevätviljalohkoilla jopa mahdollisesti syysruislohkoillakin lajimäärä oli vähän suurempi kuin syysvehnälohkoilla (vrt. MUKULA et al. 1969, M. RAATIKAINEN ja T. RAATIKAINEN 1975, M. RAATIKAINEN et al. 1979).

Syysvehnälohkoilta tavatusta lajistosta 96 taksonia kyettiin jakamaan yleisyyden perusteella luokkiin. Tulos on seuraava:

\begin{tabular}{lccccc}
\hline $\begin{array}{c}\text { Yleisyys } \\
\%\end{array}$ & $\begin{array}{c}\text { Kevätyksi- } \\
\text { vuotiset }\end{array}$ & $\begin{array}{c}\text { Syysyksi- } \\
\text { vuotiset }\end{array}$ & $\begin{array}{c}\text { Kaksi- } \\
\text { vuotiset }\end{array}$ & $\begin{array}{c}\text { Moni- } \\
\text { vuotiset }\end{array}$ & Yhteensä \\
\hline-2 & 2 & 7 & 2 & 21 & 32 \\
$3-4$ & 6 & 1 & - & 8 & 15 \\
$5-8$ & 2 & 4 & - & 8 & 14 \\
$9-16$ & 1 & 3 & - & 5 & 9 \\
$17-32$ & 4 & 2 & - & - & 14 \\
$33-64$ & 1 & 3 & - & - & 8 \\
$65-$ & 5 & 3 & 2 & 50 & 96 \\
\hline Yhteensä & 21 & 23 & & & \\
\hline
\end{tabular}


Yleisimmät kevätyksivuotiset lajit ja niiden yleisyysprosentit olivat: Chenopodium album 92, Galeopsis spp. 87, mikä lienee suurinpiirtein suvun yleisimmän lajin G. bifidan yleisyysprosentti, Polygonum aviculare 83, Erysimun cheiranthoides 74, Polygonum convolvulus 70 , Myosurus minimus 38, Fumaria officinalis 31, Gnaphalium uliginosum 27, Spergula arvensis 22 ja Polygonum lapathifolium 19. Yleisimmät lajit olivat jokseenkin samat kuin syysrukiissa, mutta $P$. aviculare, $P$. convolvulus, Fumaria officinalis ja Myosurus minimus olivat vehnässä yleisempiä kuin rukiissa ja $P$. lapathifolium oli vehnässä harvinaisempi kuin rukiissa (vrt. M. RAATIKAINEN ja T. RAATIKAINEN 1979), Vertailu kevätviljojen lajistoon osoittaa, että syysvehnässä $P$. aviculare ja Myosurus minimus olivat paljon yleisempiä ja Spergula arvensis ja Polygonum lapathifolium harvinaisempia kuin kevätviljoissa (vrt. MUKULA et al. 1969). Heinänurmissa kevätyksivuotisten yleisyys oli paljon pienempi kuin syysvehnässä ja lajien järjestyskin erosi huomattavasti syysvehnässä olleesta järjestyksestä (vrt. PAATELA 1953b, M. RAATIKAINEN ja T. RAATIKAINEN 1975).

Yleisimmät syysyksivuotiset lajit ja niiden yleisyysprosentit syysvehnässä olivat seuraavat: Matricaria spp. 87 , mikä lienee lähes yhtä suuri kuin suvun yleisimmän lajin $M$. (Tripleurospermun) inodorumin yleisyysprosentti, Viola arvensis 87 , Stellaria media 76, Myosotis arvensis 64, Lapsana communis 51, Capsella bursa-pastoris 47, Galium vaillantii 29 ja Thalaspi arvense 20. Yleisin syysyksivuotislajisto oli syysvehnässä melko samanlainen kuin syysrukiissa. Yleisimmät lajit olivat kuitenkin syysvehnässä yleisempiä kuin rukiissa ja Tripleurospermum inodorum, Capsella bursa-pastoris ja Galiumn vaillantii olivat vielä keskimääräistäkin yleisempiä vehnässä rukiiseen verrattuna (vrt. M. RAATIKAINEN ja T. RAATIKAINEN 1979). Kevätviljoissakin yleisin lajisto oli jokseenkin sama, mutta lajien yleisyysprosentit olivat yleensä vähän pienemmät kuin syysvehnässä. Tripleurospermun inodorumin, Capsella bursa-pastoriksen ja ehkä myös Galium vaillantiin yleisyysprosentit olivat kuitenkin keskimäärästä alhaisempia (vrt. MUKULA et al. 1969). Heinänurmissa edellä mainittujen syysvehnässä yleisimpien lajien yleisyysprosentit olivat vielä paljon alhaisemmat kuin rukiissa ja kevätviljoissa, mutta lajien yleisyysjärjestys oli kuitenkin samanlainen neljää yleisintä lajia lukuunottamatta, joiden keskinäinen järjestys oli toisenlainen (vrt. PAATELA 1953b, M. RAATIKAINEN ja T. RAATIKAINEN 1975).

Yleisimmät monivuotiset lajit ja niiden yleisyysprosentit olivat: Trifolium repens 31 , Ranunculus repens 29 , Equisetum arvense 28 , Veronica serpyllifolia 27, Cerastium caespitosum 28, Taraxacum spp. 25, Agropyron repens 22 ja Agrostis spp. 18. Syysvehnän viljelyalueella monivuotisten rikkaruoholajien yleisyys oli alhaisempi kuin rukiinviljelyalueella (vrt. M. RAATIKAINEN ja T. RAATIKAINEN 1979). Etenkin pohjoisen nurmiviljelyalueen rikkaruohoja oli niukasti ja eteläisen nurmiviljelyalueen rikkaruohot eivät olleet kovin yleisiä. 
Taulukko 3. Syysvehnälohkoilta tavattujen rikkaruohojen yleisyys ja yksilö- tai versotiheys koko maassa. Table 3. The frequency and number of weed plants or shoots $/ \mathrm{m}^{2}$ in winter wheat in the whole country.

\begin{tabular}{|c|c|c|c|c|c|}
\hline & $\begin{array}{l}\text { Frekvenssi \% } \\
\text { Frequency-\% }\end{array}$ & $\begin{array}{l}\mathrm{Kpl} / \mathrm{m}^{2} \\
\mathrm{No} / \mathrm{m}^{2}\end{array}$ & & $\begin{array}{l}\text { Frekvenssi } \% \\
\text { Frequency- } \%\end{array}$ & $\begin{array}{l}\mathrm{Kpl} / \mathrm{m}^{2} \\
\mathrm{No} . / \mathrm{m}^{2}\end{array}$ \\
\hline Acer platanoides & 0 & 0.0 & Festuca rubra & 0 & 0.0 \\
\hline Achillea millefolium & 14 & 0.7 & F. pratensis & 1 & 0.1 \\
\hline A. ptarmica & 5 & 0.3 & Festuca spp. & 0 & 0.0 \\
\hline Aegopodium podagraria & 0 & 0.0 & Filipendula ulmaria & 0 & 0.1 \\
\hline Agropyron repens & 22 & 4.0 & Fumaria officinalis & 31 & 2.0 \\
\hline Agrostis spp. & 18 & 1.3 & Gagea minima & 0 & 0.0 \\
\hline Alchemilla vulgaris coll. & 0 & 0.0 & Galeopsis bifida & 8 & 2,3 \\
\hline Alnus incana & 0 & 0.0 & G. speciosa & 13 & 4.8 \\
\hline Alopecurus aequalis & 2 & 0.1 & Galeopsis spp. & 87 & 28.5 \\
\hline A. geniculatus & 3 & 0.2 & Galium palustre & 1 & 0.0 \\
\hline A. pratensis & 0 & 0.0 & G. uliginosum & 0 & 0.0 \\
\hline Alopecurus spp. & 0 & 0.0 & G. vaillantii & 29 & 2.3 \\
\hline Anemone nemorosa & 1 & 0.0 & Galium spp. & 2 & 0.0 \\
\hline Angelica silvestris & 2 & 0.0 & Gnaphalium uliginosum & 27 & 8.4 \\
\hline Anthemis spp. & 1 & 0.0 & Hieracium spp. & 1 & 0.0 \\
\hline Anthriscus silvestris & 1 & 0.0 & Hypericum maculatum & 1 & 0.0 \\
\hline Arabidopsis thaliana & 3 & 0.1 & Juncus bufonius & 4 & 1.2 \\
\hline Artemisia vulgaris & 1 & 0.0 & Lamium hybridum & 9 & 1.2 \\
\hline Atriplex patula & 2 & 0.3 & L. purpureum & 15 & 0.9 \\
\hline Atriplex spp. & 0 & 0.0 & Lapsana communis & 51 & 7.1 \\
\hline Avena fatua & 0 & 0.0 & Lathyrus pratensis & 3 & 0.1 \\
\hline Barbarea vulgaris & 2 & 0.3 & Leontodon autumnalis & 5 & 0.2 \\
\hline Betula spp. & 2 & 0.3 & Linaria vulgaris & 3 & 0.1 \\
\hline Bidens tripartita & 1 & 0.0 & Luzula spp. & 0 & 0.1 \\
\hline Brassica campestris & 5 & 0.3 & Matricaria spp. & 87 & 23.1 \\
\hline Bromus sp. & 0 & 0.0 & Medicago sativa & 1 & 0.0 \\
\hline Calamagrostis spp. & 1 & 0.0 & Myosotis arvensis & 64 & 6.6 \\
\hline Campanula patula & 0 & 0.0 & M. stricta & 0 & 0.0 \\
\hline Campanula spp. & 0 & 0.0 & Myosurus minimus & 38 & 8.9 \\
\hline Capsella bursa-pastoris & 47 & 4.8 & Phleum pratense & 5 & 3.9 \\
\hline Cardaminopsis suecica & 0 & 0.0 & Phragmites communis & 1 & 0.0 \\
\hline Carex spp. & 1 & 0.0 & Plantago major & 1 & 0.0 \\
\hline Carum carvi & 1 & 0.0 & Plantago spp. & 1 & 0.0 \\
\hline Centaurea cyanus & 8 & 0.4 & Poa annua & 3 & 0.2 \\
\hline Cerastium caespitosum & 24 & 1.1 & P. pratensis s. lat. & 13 & 2.2 \\
\hline Chamaenerion angustifolium & 3 & 0.0 & P. trivialis & 12 & 2.8 \\
\hline Chenopodium album s. lat. & 92 & 27.3 & Poa spp. & 7 & 0.6 \\
\hline C. polyspermum & 3 & 0.2 & Polygonum aviculare s. lat. & 83 & 12.8 \\
\hline Chrysanthemum & & & P. convolvulus & 70 & 8.1 \\
\hline leucanthemum s. lat. & 1 & 0.0 & P. hydropiper & 7 & 0.3 \\
\hline Cirsium arvense & 16 & 0.4 & P. lapathifolium & 19 & 1.6 \\
\hline Dactylis glomerata & 0 & 0.0 & Populus tremula & 0 & 0.0 \\
\hline Deschampsia caespitosa & 3 & 0.5 & Potentilla anserina & 1 & 0.0 \\
\hline Epilobium palustre & 0 & 0.1 & $P$. norvegica & 0 & 0.0 \\
\hline Epilobium spp. & 0 & 0.0 & Prunella vulgaris & 0 & 0.0 \\
\hline Equisetum arvense & 28 & 1.6 & Ranunculus acris s. lat. & 4 & 0.2 \\
\hline E. palustre & 3 & 0.0 & $R$. auricomus coll. & 6 & 0.4 \\
\hline E. silvaticum & 5 & 0.2 & R. repens & 29 & 1.4 \\
\hline Erophila verna & 2 & 0.2 & Raphanus raphanistrum & 4 & 0.1 \\
\hline Erysimum cheiranthoides & 74 & 15.1 & Rorippa palustris & 0 & 0.0 \\
\hline
\end{tabular}




\begin{tabular}{|c|c|c|c|c|c|}
\hline & $\begin{array}{l}\text { Frekvenssi \% } \\
\text { Frequency-\% }\end{array}$ & $\begin{array}{l}\mathrm{Kpl} / \mathrm{m}^{2} \\
\mathrm{No} . / \mathrm{m}^{2}\end{array}$ & & $\begin{array}{l}\text { Frekvenssi \% } \\
\text { Frequency-\% }\end{array}$ & $\begin{array}{l}\mathrm{Kpl} / \mathrm{m}^{2} \\
\mathrm{No} . \mathrm{m}^{2}\end{array}$ \\
\hline Rubus arcticus & 0 & 0.0 & Trifolium bybridum & 8 & 1.2 \\
\hline Rubus saxatilis & 0 & 0.0 & $T$. pratense & 6 & 0.3 \\
\hline Rumex acetosa s. lat. & 4 & 0.2 & T. repens & 31 & 1.3 \\
\hline$R$. acetosella s. lat. & 4 & 0.1 & Trifolium spp. & 0 & 0.0 \\
\hline R. longifolius & 2 & 0.1 & Tussilago farfara & 0 & 0.0 \\
\hline Rumex spp., suolaheinät & 2 & 0.0 & Urtica dioica & 1 & 0.0 \\
\hline Sagina procumbens & 12 & 1.4 & Veronica agrestis & 2 & 0.1 \\
\hline Scleranthus annuus & 2 & 0.0 & V. arvensis & 5 & 0.4 \\
\hline Scutellaria galericulata & 0 & 0.0 & V. chamaedrys & 8 & 0.2 \\
\hline Secale cereale & 6 & 0.8 & V. serpyllifolia & 27 & 1.7 \\
\hline Senecio vulgaris & 1 & 0.0 & V. verna & 1 & 0.0 \\
\hline Sonchus arvensis & 14 & 0.6 & Veronica spp. & 0 & 0.2 \\
\hline S. asper & 4 & 0.2 & Vicia cracca & 5 & 0.1 \\
\hline S. oleraceus & 1 & 0.0 & $V$. hirsuta & 7 & 0.2 \\
\hline Spergula arvensis & 22 & 3.1 & V. sepium & 1 & 0.0 \\
\hline Stachys palustris & 2 & 0.0 & Vicia spp. & 0 & 0.0 \\
\hline Stellaria graminea & 1 & 0.1 & Viola arvensis & 87 & 27.4 \\
\hline S. media & 76 & 14.7 & V. montana & 1 & 0.0 \\
\hline Taraxacum spp. & 25 & 1.4 & V. palustris & 1 & 0.2 \\
\hline Thalictrum sp. & 0 & 0.0 & V. tricolor & 0 & 0.0 \\
\hline Thlaspi arvense & 20 & 1.4 & & & \\
\hline
\end{tabular}

\subsubsection{Rikkaruohojen tiheys kaikilla lobkoilla}

Syysvehnälohkoilla oli keskimäärin 257 rikkakasvia $/ \mathrm{m}^{2}$ (taulukko 3 ). Tiheys oli 43 rikkaruohoyksilöä tai -versoa suurempi kuin Lounais-Suomen alueen syysruislohkoilla (vrt. M. RAATIKAINEN ja T. RAATIKAINEN 1979). Rikkaruohotiheys oli peräti 293 yksilöä tai versoa pienempi kuin kevätviljapelloilla (vrt. MUKULA et al. 1969) ja 74 yksilöä tai versoa pienempi kuin sokerijuurikasmailla (BRUMMER et al. 1971).

Syysvehnälohkojen näytealoilta tavatut rikkaruohot jakaantuivat yksilötai versotiheyden perusteella tiheysluokkiin seuraavasti:

\begin{tabular}{rccccc}
\hline $\mathrm{Kpl} / \mathrm{m}^{2}$ & $\begin{array}{c}\text { Kevätyksi- } \\
\text { vuotiset }\end{array}$ & $\begin{array}{c}\text { Syysyksi- } \\
\text { vuotiset }\end{array}$ & $\begin{array}{c}\text { Kaksi- } \\
\text { vuotiset }\end{array}$ & $\begin{array}{c}\text { Moni- } \\
\text { vuotiset }\end{array}$ & Yhteensä \\
\hline-2 & 12 & 17 & 2 & 47 & 78 \\
$3-4$ & 1 & - & - & 3 & 4 \\
$5-8$ & 3 & - & - & - & 6 \\
$9-16$ & 3 & 1 & - & - & 4 \\
$17-$ & 2 & 2 & - & - & 4 \\
\hline & 21 & 23 & 2 & 50 & 96 \\
\hline
\end{tabular}

Kevätyksivuotisia kasveja oli syysvehnässä $44 \%$ rikkakasvien kokonaismärästä. Tiheimmässä kasvaneet kevätyksivuotiset rikkaruohot ja niiden yksilöiden osuudet syysvehnän kaikkien rikkaruohojen tiheydestä olivat: 


\begin{tabular}{lcc}
\hline & $\mathrm{Kpl} / \mathrm{m}^{2}$ & $\%$ \\
\hline Galeopsis spp. & 35,6 & 13.9 \\
Chenopodium album & 27.3 & 10.6 \\
Erysimum cheiranthoides & 15.1 & 5.9 \\
Polygonum aviculare & 12.8 & 5.0 \\
Myosurus minimus & 8.9 & 3.5 \\
Gnaphalium uliginosum & 8.4 & 3.3 \\
Polygonum convolvulus & 8.1 & 3.2 \\
Spergula arvensis & 3.1 & 1.2 \\
\hline
\end{tabular}

Galeopsis-suvun lajeista syysvehnässä esiintyivät $G$. bifida ja $G$ speciosa runsaimpina ja G. tetrahit niukkana. Tutkimusajankohtana yksilöt olivat niin nuoria, ettei niitä kyetty määrittämään lajilleen. Edellä mainitut kevätyksivuotiset lajit olivat melko samanlaiset kuin syysrukiissakin tiheimmässä kasvaneet lajit. Olennainen ero oli kivennäismaiden lajien suurempi runsaus ja eloperäisten maiden lajien pienempi runsaus syysvehnälohkoilla syysruislohkoihin verrattuna (vrt. M. RAATIKAINEN ja T. RAATIKAINEN 1979).

Kevätviljoissa ollut lajisto muistutti syysvehnässä ollutta, mutta tiheys oli kevätviljoissa paljon suurempi. Lisäksi eloperäisten maiden lajien osuus oli vähän suurempi ja kivennäismaiden lajien osuus vähän pienempi kuin syysvehnässä (vrt. MUKULA et al. 1969). Sokerijuurikasmaiden lajisto poikkesi runsaussuhteiltaan huomattavasti enemmän kuin kevätviljojen lajisto syysvehnän lajistosta (vrt. BRUMMER et al. 1971). Heinänurmissa kevätyksivuositen lajien osuus oli paljon pienempi kuin syysvehnässä, mutta osaksi niiden runsausjärjestys oli sama kuin syysvehnässä (vrt. PAATELA 1953b, M. RAATIKAINEN ja T. RAATIKAINEN 1975).

Syysyksivuotisia rikkakasveja oli syysvehnässä $42 \%$ rikkaruohojen kokonaismäärästä. Monien syysyksivuotisten lajien yksilöistä huomattava osa, jopa valtaosa esim. Stellaria mediasta, iti keväällä, joten syysyksivuotisten yksilöiden osuus oli paljon pienempi kuin edellä mainittu prosenttiluku. Runsaimmat lajit ja niiden osuudet rikkaruohojen määrästä olivat

\begin{tabular}{lcc}
\hline & $\mathrm{Kpl} / \mathrm{m}^{2}$ & $\%$ \\
\hline Viola arvensis & 27.4 & 10.7 \\
Matricaria spp. & 23.1 & 9.1 \\
Stellaria media & 14.7 & 5.7 \\
Lapsana communis & 7.1 & 2.8 \\
Myosotis arvensis & 6.6 & 2.6 \\
Capsella bursa-pastoris & 4.8 & 1.9 \\
\hline
\end{tabular}

Syysrukiissakin nämä lajit olivat runsaimpina, mutta sïnä näiden osuudet rikkaruohojen kokonaismäärästä olivat pienemmät, mikä osoittaa, että syysyksivuotiset lajit olivat erityisen tyypillisiä syysvehnän rikkaruohoja (vrt. M. RAATIKAINEN ja T. RAATIKAINEN 1979). Haitallisimpana lajina pidetään usein Matricaria (Tripleurospermum) inodorumia, joka oli Matricaria-suvun 
valtalaji. Muut syysvehnässä esiintyneet tämän suvun lajit olivat $M$. matricarioides ja $M$. recutita.

Kevätviljoissakin monet edellä mainituista lajeista olivat runsaimpia, mutta runsausjärjestys oli toisenlainen, ja monien lajien yksilötiheys oli suurempi ja osuus kaikista rikkaruohoista pienempi kuin syysvehnässä (vrt. MUKULA et al. 1969). Sokerijuurikasmaiden ja heinänurmien syysyksivuotisten rikkaruohojen koostumuksesta erosi syysvehnän rikkaruohokoostumus vielä enemmän kuin kevätviljojen (vrt. PAATELA 1953b, BRUMMER et al. 1971, M. RAATIKAINEN ja T. RAATIKAINEN 1975).

Syysvehnässä oli monivuotisten rikkaruohojen versoja $14 \%$ rikkaruohojen kokonaismäärästä. Tiheimmässä kasvaneet lajit ja niiden versojen osuudet yksilöiden ja versojen kokonaismäärästä olivat:

\begin{tabular}{lcc}
\hline & $\mathrm{Kpl} / \mathrm{m}^{2}$ & $\%$ \\
\hline Agropyron repens & 4.0 & 1.6 \\
Phleum pratense & 3.9 & 1.5 \\
Poa trivialis & 2.8 & 1.1 \\
\hline
\end{tabular}

Monivuotisten rikkaruohojen tiheys oli syysvehnässä paljon pienempi kuin syysrukiiissa ja tiheyden mukainen järjestyskin poikkesi rukiissa olleesta järjestyksestä (vrt. M. RAATIKAINEN ja T. RAATIKAINEN 1979). Syynä oli $\mathrm{mm}$. syysvehnän viljely viljojen jälkeen, jolloin nurmien rikkaruohot eivät voineet olla runsaita syysvehnässä. Esimerkiksi Phleum pratensen tiheys oli paljon pienempi kuin rukiissa, ja yli vuoden ikäisiä kasveja oli enintään 11.8 \% timoteiyksilöiden määrästä. Trifolium pratensen yksilöistä oli kuitenkin $2.5 \%$ yli vuoden ikäisiä. Tämä aiheutui siitä, että syysvehnän viljely oli keskittynyt puna-apilan viljelyalueelle selvemmin kuin rukiin viljely (vrt. M. RAATIKAINEN ja T. RAATIKAINEN 1979). Kevätviljojen, heinänurmien ja sokerijuurikasmaiden runsain monivuotinen rikkaruoho on $A$. repens, jota pidetään yhtenä pahimmista rikkaruohoistamme. Myös syysvehnässä se oli runsain, mutta muilta osin poikkesi muiden viljelykasvien monivuotisten rikkaruohojen runsausjärjestys huomattavasti syysvehnässä todetusta järjestyksestä (vrt. PAATELA 1953b, MUKULA et al. 1969, BRUMMER et al. 1971, M. RAATIKAINEN ja T. RAATIKAINEN 1975).

\subsection{Rikkaruoholajien yksilötiheyteen vaikuttavista tekijöistä}

\subsubsection{Tilan pinta-ala}

Tilakoko ei vaikuta suoranaisesti rikkaruohojen tiheyteen vaan eri ekologisten tekijöiden välityksellä. Suurten tilojen lajit olivat avoviljelysten kertarikkaruohoja (taulukot 4 ja 5). G. bifida oli rukiissa ja kevätviljoissa suurten tilojen kasvi (MUKULA et al. 1969, M. RAATIKAINEN et al. 1979). Syysvehnässä sitä oli eniten keskisuurilla tiloilla. Lapsana ja Myosotis ovat saunaku- 
Taulukko 4. Ekologisten tekijöiden vaikutukset rikkaruohojen yksilö- tai versotiheyteen. Oikeanpuoleisessa sarakkeessa olevat numerot ilmoittavat minkä tasojen välillä on merkitsevä ero ja mikä on sen merkitsevyys. Jos ero on tasojen a ja b välillä se on merkitty ykkösellä ja jos se on c:n ja d:n välillä se on merkitty kuutosella.

Table 4. The influence of different ecological factors on the plant or shoot densities of the weeds. The number on the last column gives the levels between which there is a difference and the significance of the difference. This number derives from the attched setting. If there is a difference between $a$ and $b$, it is marked by number one, if there is a difference between $c$ and $d$, it is marked by number six.

\begin{tabular}{l|c|c|c|}
\multicolumn{4}{|c}{ Tasot - Levels } \\
\hline & $\mathrm{b}$ & $\mathrm{c}$ & $\mathrm{d}$ \\
\hline $\mathrm{a}$ & 1 & 2 & 4 \\
\hline $\mathrm{b}$ & - & 3 & 5 \\
\hline $\mathrm{c}$ & - & - & 6 \\
\hline
\end{tabular}

Tasot - Leveis

Tasot ovat seuraavat:

maalajitasot: a) karkea kivennäismaa ja hiesu, b) savimaa ja c) eloperäinen maa

maaperän kosteustasot: a) poutiva, b) keskinkertainen ja c) veden vaivaama

esikasvitasot: a) kevätvilja, b) syysvilja tai syysrypsi, c) nurmi, d) muu kasvi tai kesanto

peittaustasot: a) peittaamaton ja b) peitattu

karjanlantatasot: a) lannoittamaton ja b) lannoitettu

The levels of

soil type: a) coarse mineral soil and silt, b) clay soil, c) organic soil

moisture conditions of soil: a) dry, b) medium dry, c) wet

previous crop: a) spring cereal, b) winter cereal or winter turnip rape, c) ley, d) other plant or fallow

seed dressing: a) dressed, b) not dressed

farmyard manure: a) manured, b) not manured

Index: esikasvi $=$ previous crop, karjanlannan määrä $=$ farmyard manure $($ tons), karjanlanta syksyllä $=$ farmyard manure in autumn, kylvöaika $=$ sowing time, leikkuupuintien määrä $=$ number of combine harvesting, lohkon etäisyys $=$ distance of field from farmstead $(m)$, lohkon ikä peltona $=$ age of cultivated fields (years), luokkamuuttujat $=$ class variables, maalaji $=$ soil type, maaperän kosteus $=$ moisture conditions of soil, nurmenaolovuosien määrä $=$ years as ley before the previous crop, peittaus $=$ seed dressing, regressiomuuttujat $=$ regression variables, rikkaruoholaskennan päivä $=$ date of survay, rikkaruohoruiskutusten määrä $=$ number of herbicidal treatments during 10 years, tilan peltoala $=$ arable area of farm, typpilannan määrä keväällä = nitrogen fertilization in spring $(\mathrm{kg} / \mathrm{ha})$, typpilannan määrä syksyllä = nitrogen fertilization in autumn $(\mathrm{kg} / \mathrm{ha})$, viljan peittävyys = cover percentage of cereal.

$\mathrm{df}$

$\mathrm{F}$

Erot välillä ja

merkitsevyystaso

Diff. between

Achillea millefolium

Regressiomuuttujat

Nurmenaolovuosien määrä . . . . . . . $\quad 1,18$ 
Luokkamuuttujat

Maaperän kosteus

Agropyron repens

Regressiomuuttujat

Viljan peittävyys $\ldots \ldots \ldots \ldots \ldots \ldots \ldots \ldots$

Kylvöaika .................

Nurmenaolovuosien määrä ............

Luokkamuuttujat

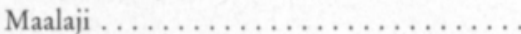

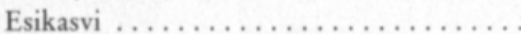

Agrostis spp.

Regressiomuuttujat

Rikkaruoholaskennan päivä .........

Nurmenaolovuosien määrä . .

Luokkamuuttujat

Maalaji . ...

2,186

$12.43^{200}$

$1^{\mathrm{xx}}$

Capsella bursa-pastoris

Regressiomuuttujat

Viljan peittävyys $\ldots \ldots \ldots \ldots \ldots \ldots \ldots \ldots$

$1,187 \quad 5,05^{*}$

Leikkuupuintien määrä $\ldots \ldots \ldots \ldots \ldots$

$1,187 \quad 10.57^{\circ}$

Tilan peltoala ...............

Cerastium caespitosum

Regressiomuuttujat

Rikkaruohoruiskutusten määrä $\ldots \ldots \ldots$.

Chenopodium album s. lat.

Regressiomuuttujat

Rikkaruohoruiskutusten märä $\ldots \ldots \ldots \ldots$

Nurmenaolovuosien määrä ............

Luokkamuuttujat

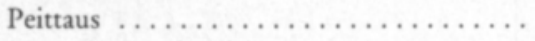

Karjanlanta syksyllä .............

Equisetum arvense

Regressiomuuttujat

Viljan peittävyys $\ldots \ldots \ldots \ldots \ldots \ldots \ldots \ldots \ldots \ldots \ldots$

Luokkamuuttujat

Peittaus . . . . . . . . . . . . . . 1,188

Equisetum silvaticum

Regressiomuuttujat

Typpilannan määrä syksyllä $\ldots \ldots \ldots \ldots \ldots$

Erysimum cheiranthoides

Regressiomuuttujat

Rikkaruohoruiskutusten määrä ........

Kylvöaika ......................

Lohkon ikä peltona $\ldots \ldots \ldots \ldots \ldots \ldots$.

Luokkamuuttujat

Esikasvi ........................

Fumaria officinalis

Regressiomuuttujat 
Lohkon ikä peltona

Luokkamuuttujat

Maaperän kosteus

Luokkamuuttujat

Maalaji

Maaperän kosteus

Galeopsis speciosa

Regressiomuuttujat

Karjanlannan määrä

Luokkamuuttujat

Maaperän kosteus . . . . . . . . . . .

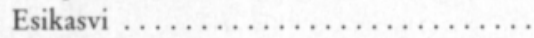

Galeopsis spp.

Regressiomuuttujat

Viljan peittävyys $\ldots \ldots \ldots \ldots \ldots \ldots \ldots$

Rikkaruohoruiskutusten määrä $\ldots \ldots \ldots$.

Lohkon etäisyys .............

Galium vaillantii

Regressiomuuttujat

Viljan peittävyys $\ldots \ldots \ldots \ldots \ldots \ldots \ldots$

Typpilannan määrä syksyllä .........

Gnaphalium uliginosum

Regressiomuuttujat

Rikkaruohoruiskutusten määrä $\ldots \ldots \ldots \ldots$

Rikkaruoholaskennan päivä .........

Luokkamuuttujat

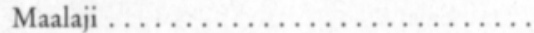

Maaperän kosteus . . . . . . . . . . .

Lamium bybridum

Regressiomuuttujat

Viljan peittävyys $\ldots \ldots \ldots \ldots \ldots \ldots \ldots$

Leikkuupuintien määrä

Lamium purpureum

Regressiomuuttujat

Kylvöaika

Lapsana communis

Regressiomuuttujat

Kylvöaika $\ldots \ldots \ldots \ldots \ldots \ldots \ldots$

Tilan peltoala

Matricaria spp.

Regressiomuuttujat

Leikkuupuintien määrä $\ldots \ldots \ldots \ldots \ldots$.

Rikkaruohoruiskutusten määrä $\ldots \ldots \ldots$.

Kylvöaika .................

Lohkon ikä peltona ..............

Luokkamuuttujat

Esikasvi

Myosotis arvensis

Regressiomuuttujat

Viljan peittävyy

Tilan peltoala
1,185

$10.17^{\mathrm{x}}$

$2,185 \quad 4.22^{x}$

$1^{\mathrm{xx}}$

$2,185 \quad 7.61^{\mathrm{xw}}$

$2,185 \quad 8.34^{\mathrm{mx}}$

$1,183 \quad 6.18^{x}$

$2,183 \quad 4.59^{x}$

$3,183 \quad 2.74^{x}$

$1^{x}, 2^{x x}, 4^{x}$

$1,187 \quad 6.47^{\prime}$

$1,187 \quad 6.28^{2}$

$1,187 \quad 9.67^{\circ}$

$1,188 \quad 14.90^{\mathrm{mox}}$

$1,188 \quad 5.80^{x}$

$1,184 \quad 4.80^{x}$

$1,184 \quad 7.30^{\mathrm{xx}}$

$2,184 \quad 5.95^{\mathrm{xx}}$

$2,184 \quad 4.85^{\mathrm{x}}$

$1,188 \quad 15.63^{\mathrm{xu}}$

$1,188 \quad 4.39^{x}$

$1,189 \quad 4.63^{x}$

$1,188 \quad 5.94^{x}$

$1,188 \quad 6.23^{x}$

$1,183 \quad 7.39^{\mathrm{xx}}$

$1,183 \quad 8.43^{\text {* }}$

$1,1834.40^{x}$

$1,183 \quad 7.30^{\circ x}$

$3,183 \quad 3.87^{x}$

$2^{x}, 3^{x x}, 4^{x}, 5^{x x}$

$1,181 \quad 7.63^{\mathrm{xx}}$

$1,181 \quad 6.38^{x}$ 


\begin{tabular}{llll}
\hline df & F & $\begin{array}{c}\text { Erot välillä ja } \\
\text { merkitsevyystaso } \\
\text { Diff. between }\end{array}$ \\
\hline
\end{tabular}

Nurmenaolovuosien määrä _....... 1,181

Typpilannan määrä keväällä .........

Luokkamuuttujat

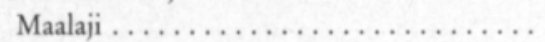

$2,181 \quad 5.46^{\mathrm{x}}$

$3,181 \quad 3.98^{\mathrm{x}}$

$1^{x}, 2^{x}$

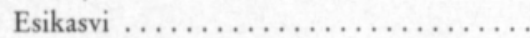

$2^{\mathrm{xx}}, 3^{\mathrm{xx}}, 4^{\mathrm{x}}, 5^{\mathrm{x}}$

Myosurus minimus

Regressiomuuttujat

Viljan peittävyys .

$1,188 \quad 4.31^{x}$

Lohkon ikä peltona

1,188

$9.50^{\mathrm{x}}$

Poa pratensis

Regressiomuuttujat

Rikkaruohoruiskutusten määrä

$1,188 \quad 15.77^{\mathrm{xx}}$

Lohkon etäisyys . . . . $\ldots \ldots \ldots \ldots \ldots \ldots \quad 1,188 \quad 4.32^{x}$

Poa trivialis

Luokkamuuttujat

Maaperän kosteus . . . . . . . . . . .

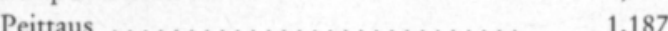

$4.37^{x}$

Polygonum convolvulus

Regressiomuuttujat

Leikkuupuintien määrä

1,189

$4.89^{\mathrm{x}}$

Polygonum lapathifolium

Regressiomuuttujat

Lohkon etäisyys $\ldots \ldots \ldots \ldots \ldots \ldots \ldots$

$1,186 \quad 5.68^{\mathrm{x}}$

Lohkon ikä peltona $\ldots \ldots \ldots \ldots \ldots \ldots$

$1,186 \quad 5.36^{x}$

Luokkamuuttujat

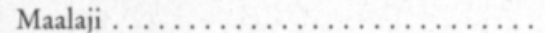

2,186

$9.71^{\mathrm{xx}}$

$1^{\mathrm{xx}}$

Ranunculus repens

Regressiomuuttujat

Rikkaruohoruiskutusten määrä $\ldots \ldots \ldots \ldots$

$1,187 \quad 10.23^{\mathrm{x}}$

Lohkon etäisyys . . . . . . . . . . .

$1,187 \quad 9.95^{x}$

Rikkaruoholaskennan päivä .........

$1,187 \quad 7.81^{\mathrm{x}}$

Sagina procumbens

Luokkamuuttujat

Maalaji . . . . . . . $2,188 \ldots \ldots \ldots \ldots$.

Sonchus arvensis

Luokkamuuttujat

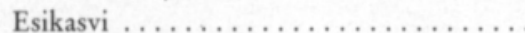

3,186

Karjanlanta syksyllä .............

1,186

$5.70^{\mathrm{xx}}$

$6.73^{x}$

Sonchus asper

Regressiomuuttujat

Leikkuupuintien määrä $\ldots \ldots \ldots \ldots \ldots \ldots \quad 1,184$

$9.18^{\mathrm{x}}$

Kylvöaika ................

$1,184 \quad 14.09^{\mathrm{xx}}$

Lohkon etäisyys ...............

$1,184 \quad 11.35^{\mathrm{xx}}$

Typpilannan määrä syksyllä .........

$1,1845.31^{x}$

Luokkamuuttujat

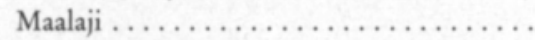

$2,184 \quad 7.27^{x x}$

Spergula arvensis

Regressiomuuttujat

Lohkon etäisyys . . . . . . . . . . .

$1,183 \quad 27.65^{\mathrm{xx}}$

Rikkaruoholaskennan päivä 
Luokkamuuttujat

$\begin{array}{llll}\text { Maalaji } \ldots \ldots \ldots \ldots \ldots \ldots \ldots \ldots \ldots \ldots \ldots \ldots & 2,183 & 12.69^{\mathrm{xx}} & 1^{\mathrm{x}} \\ \text { Esikasvi } \ldots \ldots \ldots \ldots \ldots \ldots \ldots \ldots \ldots \ldots & 3,183 & 2.60 & 1^{\mathrm{xx}}, 2^{\mathrm{x}}, 4^{\mathrm{x}}\end{array}$

Stellaria media

Regressiomuuttujat

$\begin{array}{lll}\text { Viljan peittävyys } \ldots \ldots \ldots \ldots \ldots \ldots \ldots \ldots \ldots & 1,187 & 19.36^{\mathrm{wo}} \\ \text { Kylvöaika } \ldots \ldots \ldots \ldots \ldots \ldots \ldots \ldots \ldots \ldots & 1,187 & 6.67^{\mathrm{x}} \\ \text { Lohkon ikä peltona } \ldots \ldots \ldots \ldots \ldots \ldots \ldots \ldots & 1,187 & 5.57^{\mathrm{x}}\end{array}$

Taraxacum spp.

Regressiomuuttujat

Leikkuupuintien määrä $\ldots \ldots \ldots \ldots \ldots$.

Rikkaruohoruiskutusten määrä $\ldots \ldots \ldots \ldots$

$1.183 \quad 6.90^{\mathrm{xx}}$

Lohkon etäisyys ..............

$1,183 \quad 4.96^{x}$

Rikkaruoholaskennan päivä .........

$1,183 \quad 7.87^{\circ x}$

Luokkamuuttujat

Esikasvi

Thlaspi arvense

Regressiomuuttujat

Viljan peittävyys $\ldots \ldots \ldots \ldots \ldots \ldots \ldots \ldots \quad 1,188$

$3,183 \quad 8.25^{\mathrm{mox}}$

$6^{\mathrm{xx}}$

Lohkon ikä peltona

$1,188 \quad 14.16^{\mathrm{xox}}$

Trifolium repens

Regressiomuuttujat

Rikkaruohoruiskutusten määrä $\ldots \ldots \ldots \ldots \quad 1,188 \quad 11.32^{\mathrm{mo}}$

Typpilannan määrä keväällä $\ldots \ldots \ldots \ldots \ldots \quad 1,188 \quad 7.47^{\star x}$

Veronica serpyllifolia

Regressiomuuttujat

Viljan peittävyys $\ldots \ldots \ldots \ldots \ldots \ldots \ldots$

$1,183 \quad 6.54^{x}$

Rikkaruohoruiskutusten määrä $\ldots \ldots \ldots \ldots \quad 1,183 \quad 5.60^{x}$

Typpilannan määrä syksyllä $\ldots \ldots \ldots \ldots \ldots \quad 1,183 \quad 3.93^{x}$

Luokkamuuttujat

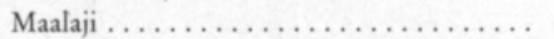

Maaperän kosteus . . . . 2,183

Viola arvensis

Regressiomuuttujat

\begin{tabular}{|c|c|}
\hline Viljan peittävyys $\ldots \ldots \ldots$ & 1,185 \\
\hline Kulvöaika & 1,185 \\
\hline Rikkaruoholaskennan päivä & 1,185 \\
\hline
\end{tabular}

Taulukko 5. Rikkaruohojen yksilöiden tai versojen kappalemäärä/ $\mathrm{m}^{2}$ eri kokoisilla tiloilla. Table 5. The plant or shoot density $\left(\mathrm{No} . / \mathrm{m}^{2}\right)$ of weeds on farms with different sizes of arable area.

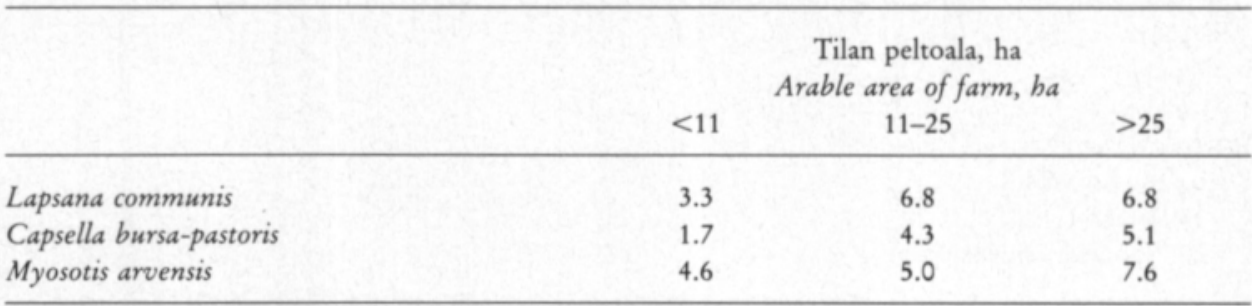


kan ohella syysviljojen tyypillisiä rikkaruohoja, jotka useita herbisidejä kestävinä ovat runsastuneet usein ruiskutetuilla lohkoilla ja niukentuneet lähinnä nurmivaiheessa. Mm. näiden tekijöiden takia viljaan erikoistuneilla, pitkän aikaa herbisidiruiskutuksia tehneillä suurtiloilla näiden kasvien tiheys oli suurin. Capsella ja Tripleurospermum inodorum, joka taulukossa 5 on yksi Matricaria-suvun lajeista, on aikaisemmin todettu samanlaisten kasvupaikkojen lajeiksi kuin Myosotis arvensis (MUKULA et al. 1969), ja tämäkin aineisto tukee päätelmää.

\subsubsection{Lobkon etäisyys talouskeskuksesta}

Lähipeltojen rikkakasvit Taraxacum ja Poa pratensis ovat myös kivennäismailla olevien nurmien lajeja (taulukot 4 ja 6) (MUKULA et al. 1969). Taraxacum on näistä todettu nurmissakin lähipeltojen lajiksi (M. RAATIKAINEN ja T. RAATIKAINEN 1975). Etäpeltojen lajit ovat lähes kaikki eloperäisillä mailla olevien avoviljelysten lajeja. Aikaisemmin näiden lajien ei ole todettu olevan etäpeltojen lajeja, mutta syysrukiistakin koottu aineisto tukee päätelmää, että $P$. lapathifolium ja Galeopsis spp. ovat etäpeltojen lajeja (M. RAATIKAINEN ja T. RAATIKAINEN 1979). Syysvehnää viljelevillä tiloilla laidunnurmet olivat usein lähipelloilla ja vaatimattomimmat kevätviljat sijaitsivat etäällä olevilla suoviljelyksillä. Lähinnä maalajien ja kasvinvuorottelun erilaisuus lienevät aiheuttaneet kasvien tiheyserot eri etäisyysksillä talouskeskuksesta olevilla lohkoilla.

\subsubsection{Lohkon ikä peltona}

Uudisviljelyksille tuodun karjanlannan ja ensimmäisten nurmikasvien siementen mukana leviävien Stellaria median ja Polygonum lapathifoliumin on todettu aikaisemmin esiintyvän jo nuorilla pelloilla ja runsastuvan niillä ensimmäisten kymmenien vuosien kuluessa (M. RAATIKAINEN ja T. RAATI-

Taulukko 6. Rikkaruohojen yksilöiden tai versojen kappalemäärä/ $\mathrm{m}^{2}$ eri etäisyydellä talouskeskuksesta olevilla syysvehnälohkoilla.

Table 6. Influence of the distance of field on the plant or shoot density $/ m^{2}$ of the taxa

\begin{tabular}{lccc}
\hline & \multicolumn{3}{c}{$\begin{array}{c}\text { Lohkon etäisyys talouskeskuksesta, .m } \\
\text { Distance of field from farmstead, }\end{array}$} \\
& $\begin{array}{l}\text { 1-199 } \\
\text { 200-799 }\end{array}$ & $800-$ \\
\hline Taraxacum spp. & 1.9 & 1.0 & 0.6 \\
Poa pratensis s. lat & 1.5 & 3.1 & 0.2 \\
Polygonum lapathifolium & 1.6 & 0.9 & 2.5 \\
Ranunculus repens & 0.9 & 0.5 & 4.0 \\
Galeopsis spp. & 22.1 & 21.2 & 37.8 \\
Sonchus asper & 0.0 & 0.1 & 0.6 \\
Spergula arvensis & 0.6 & 0.9 & 12.7 \\
\hline
\end{tabular}




\begin{tabular}{lrcr}
\hline & \multicolumn{3}{c}{$\begin{array}{c}\text { Lohkon ikä, vuotta } \\
\text { Age of field, years } \\
90-119\end{array}$} \\
& $0-89$ & $120-$ \\
\hline Stellaria media & 15.9 & 15.6 & 6.4 \\
Polygonum lapathifolium & 1.3 & 2.2 & 0.3 \\
Matricaria spp. & 18.3 & 26.0 & 18.3 \\
Myosurus minimus & 3.3 & 10.7 & 9.3 \\
Erysimum cheiranthoides & 10.0 & 13.8 & 17.0 \\
Fumaria officinalis & 1.1 & 1.7 & 2.4 \\
Thlaspi arvense & 0.3 & 0.7 & 3.4 \\
\hline
\end{tabular}

KAINEN 1972). Tämän aineiston mukaan lajit näyttävät myöhemmin niukentuvan pellon vanhetessa (taulukot 4 ja 7), ja sitä vahvistavat aikaisemmatkin mutta päätelmien tekoon liian pienet aineistot. Lohkon vanhetessa runsastuvia lajeja oli useita, ja näistä useimmat olivat joko selvästi runsastuneet tai ainakin näyttäneet runsastuvan aikaisempien tutkimusten mukaan vajaan 100 vuoden ikäisillä pelloilla (M. RAATIKAINEN ja T. RAATIKAINEN 1972, 1979). Pellon vanhetessa sen ravinteisuus ja $\mathrm{pH}$ kohoavat ilmeisesti saman tapaisesti kuin puutarhoissakin, ja tästä on seurauksena, että varsinkin vaateliaimpien rikkakasvien, kuten esim. Fumaria officinaliksen, elinmahdollisuudet paranevat ja niiden yksilötiheys suurenee (vrt. JALAS ja HONKALA 1962, SAARISALO-TAUBERT 1963, BORG 1964).

\subsubsection{Maalajit}

Maalaji on suurimpia rikkaruohojen tiheyteen vaikuttaneita tekijöitä. Syysvehnästä kootun aineiston avulla voitiin verrata kasvien suhdetta karkeisiin kivennäismaihin ja savimaihin. Eloperäisiltä mailta koottu aineisto oli pieni ja sen sisäinen vaihtelu siksi suuri, ettei tilastomatemaattisia eroja todettu kuin muutamissa tapauksissa (taulukot 4 ja 8). Suurin osa niistä lajeista, jotka voitiin luokitella, oli karkeiden kivennäismaiden lajeja, joiden tiheys oli savimailla pieni. Näistä lajeista Myosotis arvensis ja Agropyron repens on todettu myös kevätviljapelloilla ja heinänurmissa kivennäismaiden tai karkeiden kivennäismaiden lajeiksi, ja Galeopsis bifidan on todettu karttavan savimaita kevätviljapelloillakin (PAATELA 1953b, MUKULA et al. 1969, M. RAATIKAINEN ja T. RAATIKAINEN 1975). Agrostis, joka oli etupäässä $A$. tenuista, oli myös nurmissa orgaanisia ja karkeita kivennäismaita suosiva laji. Polygonum lapathifolium, Spergula arvensis ja Gnaphalium uliginosum olivat kevätviljoissa ja syysrukiissa vielä selvemmin orgaanisten maiden kasveja kuin syysvehnässä.

Syysvehnän tyypillisten kasvupaikkojen, savimaiden lajeja ei todettu yhtään. Sellaisia saattoivat olla mm. Cirsium arvense, Fumaria officinalis, Galium vaillantii, Myosurus minimus ja Sonchus arvensis, joita kuitenkin oli melkoisesti myös muilla maalajeilla. 
Taulukko 8. Rikkaruohojen yksilö- tai versomäärä/ $\mathrm{m}^{2}$ eri maalajeilla.

Table 8. Number of weed plant or shoot $/ \mathrm{m}^{2}$ on different soil types.

$\begin{array}{ccc}\begin{array}{c}\text { Karkeat kiven- } \\ \text { näismaat }\end{array} & \begin{array}{c}\text { Savi- } \\ \text { maat }\end{array} & \begin{array}{c}\text { Eloperäiset } \\ \text { maat }\end{array} \\ \begin{array}{c}\text { Coarse mineral } \\ \text { soils and silts }\end{array} & \text { Clay soils } & \text { Organic soils }\end{array}$

Karkeiden kivenäismaiden lajit

Species of coarse mineral soils

$\begin{array}{lrll}\text { Galeopsis bifida } & 8.7 & 0.5 & 0.6 \\ \text { Myosotis arvensis } & 10.9 & 5.1 & 0.9 \\ \text { Sagina procumbens } & 4.5 & 0.5 & 0.0 \\ \text { Veronica serpyllifolia } & 4.7 & 0.8 & 0.0\end{array}$

Karkeiden kivennäismaiden ja

eloperäisten maiden lajit

Species of coarse mineral soils

and organis soils

$\begin{array}{lrrr}\text { Agropyron repens } & 4.6 & 2.0 & 14.7 \\ \text { Agrostis spp. } & 3.7 & 0.2 & 5.6 \\ \text { Gnaphalium uliginosum } & 13.9 & 5.0 & 26.4 \\ \text { Polygonum lapathifolium } & 2.0 & 0.5 & 14.9 \\ \text { Spergula arvensis } & 2.1 & 0.5 & 43.2\end{array}$

Eloperäisten maiden lajit

Species of organic soils

Sonchus asper

0.0

0.1

1.8

\subsubsection{Maaperän kosteus}

Maaperän kosteus vaikutti monen rikkaruoholajin tiheyteen, mutta erot eivät olleet useinkaan aivan selkeitä (taulukot 4 ja 9). Tulokset olivat useimpien lajien kohdalla samanlaiset kuin aikaisemmin julkaistuissa tuloksissa (JALAS ja JUUSELA 1959, MUKULA et al. 1969, M. RAATIKAINEN ja T. RAATIKAINEN 1975, 1979). Huomattavin poikkeus oli Viola arvensis, joka kasvoi syysvehnäpelloissa kosteammalla alustalla kuin kevätviljapelloissa.

Taulukko 9. Rikkaruohojen yksilöiden tai versojen kappalemäärä/ $\mathrm{m}^{2}$ eri kosteilla kasvualustoilla. Table 9. Influence of soil moisture conditions on the number of weed plants or shoots $/ \mathrm{m}^{2}$.

\begin{tabular}{lccc}
\hline & Poutiva & $\begin{array}{c}\text { Keskin- } \\
\text { kertainen } \\
\text { Medium dry }\end{array}$ & $\begin{array}{c}\text { Veden } \\
\text { vaivaama } \\
\text { Wet }\end{array}$ \\
\hline Fumaria officinalis & 2.5 & 1.5 & 1.3 \\
Achillea millefolium & 0.6 & 0.4 & 2.8 \\
Viola arvensis & 17.0 & 24.3 & 22.2 \\
Galeopsis bifida & 0.2 & 2.4 & 4.8 \\
Gnaphalium uliginosum & 2.8 & 7.2 & 33.7 \\
Poa trivialis & 0.6 & 2.9 & 4.7 \\
Veronica serpyllifolia & 0.7 & 1.2 & 9.1 \\
\hline
\end{tabular}


Poutivat savimaat lienevät kuitenkin $V$. arvensikselle liian kuivia ja kuorettuvia, joten ERVIÖn (1982) toteama myöhäinen taimettuminen ei onnistu niissä yhtä hyvin kuin kevätviljapeltojen kevyemmillä maalajeilla. Achillea millefoliumin tiheys oli syysvehnässä suurin kosteilla paikoilla, vaikka se menestyy kevätviljoissa ilmeisesti parhaiten kuivilla kasvualustoilla (vrt. MUKULA et al. 1969).

\subsubsection{Leikkuupuintikertojen määrä}

Leikkuupuintiin siirryttäessä rikkaruohojen siementen tuottamiskausi piteni, leikkuukorkeus kohosi ja entistä suurempi osa siemenistä jäi peltoihin. Samanaikaisesti yleistyi herbisidien käyttö. Näistä oli seurauksena, että kookaskasvuiset, viljakasvustoissa kilpailukykyiset ja/tai herbisidejä kestävät lajit kuten Tripleurospermum inodorum, Polygonum convolvulus ja Lamium hybridum runsastuivat (taulukot 4 ja 10). Vastaavasti herbisideille herkät lajit, kuten Capsella bursa-pastoris ehkä myös Chenopodium album, Erysimum cheiranthoides ja Galeopsis spp. niukentuivat, vaikka leikkuupuinti yksinään lienee runsastuttanut niitä. Taraxacumin niukentuminen lienee näennäistä ja aiheutunee sïtä, että nurmien rikkaruohona sillä ei ollut mahdollisuutta kasvaa lohkolla, jossa viljeltiin viljoja useana vuonna peräkkäin. Leikkuupuinnin on todettu jo aikaisemmin vaikuttaneen monen tässäkin mainitun lajin runsastumiseen (esim. PETZOLDT 1959, AAMISEPP et al. 1967, MUKULA et al. 1969, M. RAATIKAINEN ja T. RAATIKAINEN 1979).

\subsubsection{Herbisidikäsittelyjen määrä}

Useina vuosina peräkkäin toistuvat rikkaruohoruiskutukset vähensivät käytetyille torjunta-aineille herkkien rikkaruohojen yksilötiheyttä. Tällaisia lajeja olivat mm. Galeopsis-lajit, Chenopodium album ja Erysimum cheiranthoides (taulukot 4 ja 11). Herbisidikäsittelyt näyttävät myös alentaneen

Taulukko 10. Lohkolla kymmenen vuoden aikana tehtyjen leikkuupuintikertojen määrän vaikutus rikkaruohojen yksilömäärään $\left(\mathrm{kpl} / \mathrm{m}^{2}\right)$.

Table 10. Influence of combine harvesting during the last ten years on the number of weed plants or shoots/ $m^{2}$.

\begin{tabular}{lrrrr}
\hline & \multicolumn{5}{c}{ Leikkuupuintikertoja } \\
& $0-4$ & $5-6$ & $7-8$ & $>8$ \\
\hline Capsella bursa-pastoris & 9.4 & 4.5 & 2.1 & 3.9 \\
Taraxacum spp. & 4.4 & 1.2 & 0.3 & 0.4 \\
Polygonum convolvulus & 3.2 & 8.5 & 8.3 & 6.7 \\
Sonchus asper & 0.0 & 0.0 & 0.4 & 0.3 \\
Matricaria spp. & 11.3 & 14.0 & 22.8 & 35.5 \\
Lamium hybridum & 0.0 & 0.3 & 1.9 & 2.0 \\
\hline
\end{tabular}


Taulukko 11. Rikkaruohojen yksilö- tai versomäärän $\left(\mathrm{kpl} / \mathrm{m}^{2}\right)$ riippuvuus $\mathrm{kymmenen} \mathrm{viime} \mathrm{vuoden}$ aikana tehtyjen rikkaruohoruiskutuskertojen määrästä.

Table 11. Influence of the number of herbicidal treatments during the last ten years on the number of weed plants or shoots $/ \mathrm{m}^{2}$.

\begin{tabular}{lrrrr}
\hline & \multicolumn{4}{c}{$\begin{array}{c}\text { Ruiskutuskertoja } \\
\text { Number of herbicidal treatments }\end{array}$} \\
& $0-3$ & $4-5$ & $6-7$ & $8-9$ \\
\hline Cerastium caespitosum & 1.9 & 1.1 & 1.0 & 0.3 \\
Galeopsis spp. & 34.7 & 29.0 & 21.8 & 16.6 \\
Gnaphalium uliginosum & 14.7 & 8.5 & 4.9 & 4.8 \\
Ranunculus repens & 2.7 & 1.1 & 1.1 & 0.5 \\
Taraxacum spp. & 3.8 & 1.2 & 0.8 & 0.0 \\
Trifolium repens & 2.4 & 0.9 & 0.8 & 0.9 \\
Veronica serpyllifolia & 3.0 & 2.1 & 0.7 & 0.8 \\
Poa pratensis s.lat. & 2.3 & 6.8 & 0.1 & 0.1 \\
Chenopodium album s. lat. & 32.5 & 23.7 & 29.2 & 14.3 \\
Erysimum cheiranthoides & 23.9 & 9.7 & 15.3 & 7.7 \\
Matricaria spp. & 18.7 & 18.1 & 23.7 & 24.3 \\
Fumaria officinalis & 0.2 & 1,0 & 2.2 & 2.7 \\
\hline
\end{tabular}

useiden monivuotisten, nurmille tyypillisten kasvilajien, kuten Cerastium caespitosumin, Poa pratensiksen, Ranunculus repensin, Taraxacumin ja Trifolium repensin tiheyttä. Tämä on kuitenkin useissa tapauksissa näennäistä ja aiheutuu siitä, että lohkoilla, joilla käytettiin usein herbisidejä ei ollut nurmia ja nurmirikkaruohoille sopivia kasvuolosuhteita. Osaksi herbisidit myös tehosivat näihin lajeihin hyvin, mikä näkyy $\mathrm{mm}$. kotimaisiin tutkimuksiin perustuvasta piirroksesta 2, jonka M. RAATIKAINEN et al. (1971) ovat julkaisseet.

Herbisidikäsittelyt ovat runsastuttaneet etenkin MCPA:ta kestäviä lajeja, kuten Fumaria officinalista ja mahdollisesti Tripleurospermum inodorumiakin, joka kuitenkin myöhemmin seosvalmisteiden tultua käyttöön näyttää niukentuneen (taulukot 4 ja 11).

Rikkaruohojen pitkäaikaisen torjunnan on todettu muuttaneen peltojen kasvikoostumusta (MUKULA et al. 1969, M. RAATIKAINEN ja T. RAATIKAINEN 1979), mutta vielä suuremmat muutokset ovat havaittavissa niissä maissa, joissa herbisidien käyttö on ollut pitkäaikaisempaa ja yleisempää (esim. SCHUBERT et al. 1975).

\subsubsection{Esikasvi}

Esikasvin vaikutus rikkaruohokoostumukseen on melko suuri, ja se on todettu useissa tutkimuksissa (GRANSTRÖM 1962, M. RAATIKAINEN ja T. RAATIKAINEN 1964, 1971, 1979, MUKULA et al. 1969, KAUHANEN 1975). Tässä tutkimuksessa todettiin kevätviljojen jälkeen kasvavan tyypillisiä kevätviljojen kevätitoisia kertarikkaruohoja ja kyntöä kestäviä kestorikkaruohoja tiheämmässä kuin muiden esikasvien jälkeen (taulukot 4 ja 12). 
Taulukko 12. Rikkaruohojen yksilöiden tai versojen kappalemäärä/ $\mathrm{m}^{2}$ eri esikasvien jälkeen viljellyssä syysvehnässä.

Table 12. Influence of the previous crop on the number of weed plants or shoots $/ \mathrm{m}^{2}$.

\begin{tabular}{cccc}
\multicolumn{4}{c}{ Esikasvit - Previous crop } \\
Kevätvilja & Syysvilja & Nurmi & Muut \\
Spring cereal & Winter cereal & Ley & Others
\end{tabular}

Kevätviljan jälkeen tiheimmässä

Highest density after spring cereal

Galeopsis speciosa

9.7

2.5

2.3

3.8

Sonchus arvensis

1.6

0.1

0.4

Erysimum cheiranthoides

22.2

10.6

11.1

12.0

Viljojen jälkeen tiheimmässä

Highest density after cereals

Matricaria spp.

20.6

28.9

9.9

14.9

Myosotis arvensis

9.3

6.3

4.2

2.8

Nurmen ja kevätviljan jälkeen tiheimmässä

Highest density after ley and spring cereal

Agropyron repens

2.3

1.7

12.5

0.1

Nurmen jälkeen tiheimmässä

Highest density after ley

Taraxacum spp.

Riviviljelykasvien, nurmen ja kevätviljan

jälkeen tiheimmässä

Highest density after annual row crop,

ley or spring cereal

Spergula arvensis

1.0

0.6

1.9

11.1

Viljojen jälkeen kasvoi tyypillisiä syysitoisia kertarikkakasveja ja nurmen jälkeen kyntämällä melko hyvin tuhoutuvia Taraxacum-lajeja ja kyntöä kestävää Agropyron repensiä. Saadut tulokset ovat hyvin samanlaiset kuin edellä mainituissa tutkimuksissa. Täten aikaisemmat tulokset vahvistuivat ja ennestään mainitsemattomien lajien todettiin nyt olevan runsaita tiettyjen esikasvien jälkeen myös syysvehnässä, josta aikaisemmat tiedot ovat puuttuneet.

Esikasvia edeltävienkin viljelykasvien vaikutus tuntuu syysvehnäpellon lajikoostumuksessa (taulukot 4 ja 13). Mitä useampana vuonna ennen esikasvia on viljelty nurmikasveja sitä enemmän syysvehnälohkolla oli monivuotisia vanhojen nurmien rikkakasveja, esimerkiksi Achillea millefoliumia ja Agrostis tenuista. Myös kaikenikäisissä nurmissa hyvin menestyvä Agropyron repens oli tällaisilla paikoilla runsaana. Vaikeammin tulkittava oli Myosotiksen ja Chenopodiumin esiintyminen runsaana tällaisissa tapauksissa. Aikaisemmin on todettu ruispelloissakin eräiden avoviljelysten rikkaruohojen olevan runsaita tällaisissa tapauksissa (M. RAATIKAINEN ja T. RAATIKAINEN 1979). 
Taulukko 13. Esikasvia edeltävien kolmen vuoden aikaisten nurmien vaikutus syysvehnän rikkakasvien yksilö- tai versomäärään $\left(\mathrm{kpl} / \mathrm{m}^{2}\right)$.

Table 13. Influence of the age of ley on the weed plant or shoot density $/ \mathrm{m}^{2}$. The age of ley is counted from three years preceeding the previous crop.

\begin{tabular}{lcccc}
\hline & \multicolumn{5}{c}{$\begin{array}{c}\text { Nurmenaolovuosien märä } \\
\text { Age of ley, years } \\
\end{array}$} & 0 & 1 & 2 & 3 \\
\hline Achillea millefolium & 0.4 & 0.2 & 0.5 & 1.9 \\
Agrostis spp. & 0.5 & 0.1 & 1.7 & 4.5 \\
Myosotis arvensis & 5.5 & 6.9 & 7.8 & 5.7 \\
Agropyron repens & 0.4 & 1.9 & 7.6 & 12.5 \\
Chenopodium album s. lat. & 18.1 & 30.1 & 33.7 & 36.7 \\
\hline
\end{tabular}

\subsubsection{Karjanlanta}

Karjanlannan mukana on kulkeutunut rikkaruohojen siemeniä, mutta viime vuosikymmeninä ei kukaan ole selvittänyt minkä lajien siemeniä ja miten paljon siemeniä kulkeutuu karjanlannan mukana. Olosuhteet ovat suuresti muuttuneet siitä kun viimeiset tutkimukset on tehty. Taulukoiden 4 ja 14 mukaan kolmen lajin runsaus oli suurin karjanlantaa saaneilla lohkoilla. Kyseisten lajien siemeniä saattoi kulkeutuakin karjanlannan mukana, mutta ainakaan Sonchus arvensis -yksilöt eivät olleet sirkkataimia, ja täten tapaus osoittaa vain, että peltovalvattia kasvaville lohkoille levitettiin karjanlantaa.

\subsubsection{Kylvöaika}

Mitä aikaisemmin syysvehnä kylvettiin sitä pitempi aika rikkaruohoille jäi itämiseen. Kuitenkin monet syksyllä itäneet yksivuotiset kasvit esim. Galeopsis-yksilöt kuolivat talvikautena ja vain syysyksivuotisista suuri osa jäi jäljelle. Taulukoiden 4 ja 15 mukaan vain Erysimum cheiranthoideksen ja Viola arvensiksen runsaus oli sitä suurempi mitä aikaisemmin kylvö tehtiin. Lamium purpureumin, Stellaria median ja Lapsana communiksen tiheys oli

Taulukko 14. Rikkaruohojen yksilöiden tai versojen kappalemäärä/ $\mathrm{m}^{2}$ karjanlannalla lannoittamattomilla ja lannoitetuilla lohkoilla.

Table 14. Number of weed plants or shoots $/ \mathrm{m}^{2}$ on fields without farmyard manure and with farmyard manure in autumn.

\begin{tabular}{lcc}
\hline & $\begin{array}{c}\text { Lannoittamaton } \\
\text { Not manured }\end{array}$ & $\begin{array}{c}\text { Lannoitettu } \\
\text { Manured }\end{array}$ \\
\hline Chenopodium album s. lat. & 22.7 & 33.9 \\
Erysimum cheiranthoides & 12.2 & 22.7 \\
Sonchus arvensis & 0.3 & 1.8 \\
\hline
\end{tabular}


Taulukko 15. Rikkaruohojen yksilöiden tai versojen kappalemäärä/ $\mathrm{m}^{2}$ eri aikoina kylvetyillä syysvehnälohkoilla.

Table 15. Influence of sowing date of winter wheat on weed plant or shoot density $/ \mathrm{m}^{2}$.

Kylvöaika - Sowing date

9.-28. VIII 29. VIII-7. IX 8. IX-8. X.

Erysimum cheiranthoides

Viola arvensis

Matricaria spp.

Sonchus asper

Agropyron repens

Lamium purpureum

Stellaria media

Lapsana communis

$\begin{array}{rrr}21.7 & 11.8 & 10.7 \\ 27.4 & 25.0 & 17.1 \\ 26.7 & 15.2 & 26.4 \\ 0.3 & 0.0 & 0.3 \\ 1.5 & 3.6 & 3.6 \\ 0.1 & 1.2 & 1.2 \\ 6.2 & 15.8 & 14.5 \\ 3.4 & 7.5 & 6.9\end{array}$

sitä suurempi mitä myöhemmin kylvö tehtiin. Tämä lienee ainakin osaksi näennäistä ja aiheutuu siitä, että eteläisehköjen lajien pääkasvupaikoilla kylvöt tehtiin myöhään. Agropyron repensin tiheys oli sekä rukiissa (M. RAATIKAINEN ja T. RAATIKAINEN 1979) että syysvehnässä suurin myöhään kylvetyillä lohkoilla.

\subsubsection{Peittaus}

Peittaus saattoi vaikuttaa rikkakasvien tiheyteen (taulukot 4 ja 16), mutta todennäköisemmin saadut tulokset kuvastavat jotakin muita peittaukseen korrelaatiossa olevia vaikuttajia. Peittauksen vaikutukset tuntuivat todennäköisesti viljan kilpailukyvyn parantumisena ja heikosti kilpailukykyisten rikkaruohojen tiheyksien alentumisina ja biomassojen pienentymisinä.

Taulukko 16. Rikkaruohojen yksilöiden tai versojen kappalemäärä/ $\mathrm{m}^{2}$ peittaamattomalla ja peitatulla siemenellä kylvetyillä lohkoilla.

Table 16. Number of weed plants or shoot $/ \mathrm{m}^{2}$ on fields sown seeds without seed dressing and with seed dressing.

$\begin{array}{cc}\text { Peittaamaton } & \text { Peitattu } \\ \text { No seed dressing } & \text { Seed dressing }\end{array}$

Peittaamattomilla tiheimmässä

Highest density on fields

without seed dressing

Equisetum arvense

Poa trivialis

3.5

1.1

Peitatulla tiheimmässä

Highest density on fields

with seed dressing

Chenopodium album s. lat.

10.7

25.6 


\subsubsection{Kevätlannoitus}

Keväällä annettu typpilannoitus suurensi syysvehnän biomassaa ja paransi sen kilpailukykyä moniin rikkaruohoihin nähden. Typpilannoituksen ei todettu vaikuttaneen rikkaruohojen tiheyttä lisäävästi lukuunottamatta Myosotis arvensista ja Trifolium repensiä (taulukko 4). Tuloksiin tulee suhtautua varauksellisesti.

\subsubsection{Rikkaruohoruiskutus}

Tässä tutkimuksessa oleva rikkaruohoaineisto on koottu rikkaruohoruiskutuksen ajaksi muovilla peitetyiltä aloilta, ja kuvastaa siten tilannetta millainen rikkaruoholajisto ja sen koostumus olisivat olleet jos ruiskutus olisi jäänyt tutkimusvuonna tekemättä. Kun syysvehnälohkoista käsiteltiin suurin osa herbisideillä saatiin aineiden tehosta rikkakasvien ja syysvehnän biomassaan suurehko aineisto, jollaista ei aikaisemmin koottu. Tämän osatutkimuksen tulokset julkaistaan myöhemmin erillisenä osajulkaisuna.

\subsubsection{Rikkaruoholajien yksilötiheys tutkimuskauden eri aikoina}

Syysvehnälohkoilla iti keväällä ja kevätkesällä rikkakasveja ja yksilötiheys suureni. Samanaikaisesti kasvitaudit, eläimet, yksilöiden väliset kilpailutekijät ja abioottiset tekijät alensivat yksilötiheyttä. Varsinkin lajin sisäisten ja lajien välisten kilpailutekijöiden osuus näytti suurenevan biomassan suurentuessa. Täten yksilötiheydet muuttuivat lyhyenä tutkimuskautenakin. Taulukoiden 4 ja 17 mukaan Agrostis tenuis, Gnaphalium uliginosum, Ranunculus repens ja Spergula arvensis -lajien yksilötiheys suureni kesäkuun alkupäivinä. Tämän aiheutti itäminen, mutta osaksi tihentyminen oli näennäistä ja aiheutui sïtä, että näiden lajien taajakkoalueet, pohjoisimmat alueet tutkittiin myöhemmin kuin niiden harvakkoalueet. Viola arvensiksen tiheydessä saattoi olla vielä itämisenkin aiheuttamaa tiheyden kohoamista, mutta lopulta

Taulukko 17. Rikkaruohojen yksilöiden tai versojen kappalemäärä/ $\mathrm{m}^{2}$ syysvehnälohkoilla kesäkuun eri aikoina.

Table 17. Weed plant or shoot densities $/ \mathrm{m}^{2}$ on different dates in June.

\begin{tabular}{lrrr}
\hline & \multicolumn{4}{c}{ Kesäkuun päivät - Dates in June } \\
& 1.-4. & 5.-6. & 7.-18. \\
\hline Taraxacum spp. & 1.8 & 1.4 & 0.5 \\
Viola arvensis & 22.3 & 26.0 & 19.3 \\
Agrostis spp. & 0.3 & 1.8 & 1.2 \\
Ranunculus repens & 1.4 & 0.5 & 1.9 \\
Gnaphalium uliginosum & 3.4 & 8.8 & 10.6 \\
Spergula arvensis & 0.6 & 1.3 & 6.8 \\
\hline
\end{tabular}


myös kuolleisuutta. Aikaisemmin on todettu G. uliginosumin tiheyden kohoavan syysrukiissa samalla tavoin kuin syysvehnässä. Myös $R$. repensin ja $V$. arvensiksen tiheyden muutokset ovat olleet rukiissa samankaltaiset kuin syysvehnässä mutteivat tilastollisesti merkitseviä (M. RAATIKAINEN ja T. RAATIKAINEN 1979).

\subsubsection{Viljan peittäryys}

Huonosti talvehtineet, harvat ja aukkoiset syysvehnäkasvustot rikkaruohottuivat. Tiheät viljakasvustot taas tukahduttivat rikkaruohoja. Taulukoiden 4 ja 18 mukaan kuitenkin vain Agropyron repensin, Thlaspi arvensen ja Fumaria officinaliksen tiheydet olivat suurimmat syysvehnäkasvustoissa, joissa viljan peittävyys oli pieni. Kyseessä olivat heikohkot yksivuotiset kilpailijat ja viljan kanssa erittäin kilpailukykyinen $A$. repens, jonka kasvupaikoilla, karkeilla kivennäismailla syysvehnä talvehti yleensä heikommin kuin savimailla. Monien rikkaruoholajien yksilötiheys oli suurin peittävissä syysvehnäkasvustoissa. Nämä lajit olivat yleensä syysitoisia kertarikkaruohoja, joiden kilpailukyky oli hyvä muttei sellainen, että ne olisivat kyenneet tukahduttamaan syysvehnää. Julkaisemattoman aineistomme mukaan näistä lajeista ainakin Stellaria media talvehti sitä paremmin mitä tiheämpi syysviljakasvusto oli. Sen talvehtimista näytti edistävän syysvehnäkasvuston hyvä hoito. Kevätyksivuotisista lajeista monet olivat varjostusta sietäviä ja kosteutta vaativia ja tällaiset olosuhteet vallitsivat tiheissä syysvehnäkasvustoissa. Hyvin tiheissä syysvehnäkasvustoissa monet rikkaruohot kärsivät kuitenkin valon puutteesta myöhemmin kesällä.

Taulukko 18. Rikkaruohojen yksilöiden tai versojen kappalemäärä/ $\mathrm{m}^{2}$ eri tiheissä syysvehnäkasvustoissa. Table 18. Influence of percentage of area covered by winter wheat on the weed plants or shoots $/ \mathrm{m}^{2}$.

\begin{tabular}{|c|c|c|c|c|}
\hline & \multicolumn{4}{|c|}{$\begin{array}{c}\text { Viljan peittävyys (\%) ja lohkojen lukumäärä (n) } \\
\text { Percentage of area covered by winter wheat and } \\
\text { number }(n) \text { of field investigated }\end{array}$} \\
\hline & $\begin{array}{l}1-20 \\
(42)\end{array}$ & $\begin{array}{c}21-40 \\
(51)\end{array}$ & $\begin{array}{c}41-60 \\
(37)\end{array}$ & $\begin{array}{c}61-100 \\
(59)\end{array}$ \\
\hline Agropyron repens & 7.0 & 2.9 & 1.7 & 1.6 \\
\hline Thlaspi arvense & 2.0 & 1.5 & 0.9 & 0.9 \\
\hline Fumaria officinalis & 3.1 & 0.9 & 2.3 & 1.0 \\
\hline C.tpsella bursa-pastoris & 2.9 & 7.0 & 4.7 & 2.8 \\
\hline Equisetum arvense & 0.9 & 1.3 & 0.8 & 2.0 \\
\hline Viola arvensis & 20.7 & 23.0 & 21.7 & 24.4 \\
\hline Veronica serpyllifolia & 0.7 & 0.9 & 2.6 & 1.8 \\
\hline Galeopsis spp. & 24.3 & 23.2 & 18.8 & 29.2 \\
\hline Galium vaillantii & 1.0 & 0.3 & 2.5 & 3.9 \\
\hline Stellaria media & 7.0 & 5.2 & 15.4 & 23.3 \\
\hline Myosurus minimus & 2.5 & 8.5 & 10.4 & 10.2 \\
\hline Myosotis arvensis & 4.2 & 5.5 & 6.4 & 7.5 \\
\hline Lamium bybridum & 0.4 & 0.1 & 0.1 & 3.4 \\
\hline
\end{tabular}


Galium vaillantiin ja Stellaria median tiheyden on todettu olleen ruiskasvustoissakin suurimman tiheissä kasvustoissa (M. RAATIKAINEN ja T. RAATIKAINEN 1979). Viola arvensiksen ja Galeopsiksen tiheydet olivat ruiskasvustoissa toisenlaisia kuin syysvehnäkasvustoissa.

\section{Loppupäätelmät ja ehdotukset}

Syysvehnän viljelystä on Suomessa tehty lukuisia tutkimuksia lähinnä valtion tutkimus- ja tarkastuslaitosten sekä yksityisten tutkimuslaitosten toimesta. Tulokset on julkistettu yleensä suomenkielisinä kotimaisissa sarjoissa, joten suomenkieltä taitamattoman on vaikea saada selkoa syysvehnän viljelystä Suomessa. Enin osa artikkeleista on tarkoitettu neuvojille ja viljelijöille. Niitä on julkaistu etenkin tutkimus-, opetus- ja tarkastuslaitosten, neuvontajärjestöjen ja kustannusliikkeiden toimesta.

Tutkimustuloksia on selostettu ja sovellettu välittäjille ja käyttäjille mm. Helsingin yliopistossa ja maatalouskouluissa, mutta viljelijä on saanut niistä suurimman osan lähinnä neuvontajärjestöjen, kaupallisten yritysten, joukkotiedotusvälineiden, ammattijärjestöjen ja tuttavien välityksellä.

Tämä selvitys osoittaa, että uusimmat tulokset on yleensä otettu nopeasti käyttöön valistuneimpien viljelijöiden tiloilla, mutta hajonta oli hyvin suuri, ja osa viljeli edelleen perinnäisiä tapoja noudattaen. Tutkimustulosten hyödyntämistä tulisi kohdistaa etenkin valistumattomimmille viljelijöille ja heidätkin tulisi saada noudattamaan parhaita ja kannattavimpia viljelytapoja. Helppotajuinen neuvonta, mm. lajikkeita ja lannoitteita koskeva, oli otettu vastaan nopeammin kuin vaikeatajuinen, $\mathrm{mm}$. kasvinsuojelua koskeva. Opaskirjaset tulisi tehdä viljelijälle käyttökelpoisemmiksi, viljelykasvi- ja aluekohtaisiksi, suomen ja ruotsin kielisiksi, kannattavuuslaskelmat huomioonottaviksi eikä vain tiettyjä osakysymyksiä koskeviksi. Monissa tapauksissa neuvonnan tulisi olla entistä enempi tila- ja viljelyaukeakohtaista. Tutkimustarpeesta ja neuvontatulosten noudattamisesta tulisi ajoittain tehdä selvityksiä ja kohdistaa tutkimus ja neuvonta suurimpiin ongelmiin.

Tässä tutkimuksessa todettiin, että monet tarkastelun kohteena olleet tekijät eivät olleet rikkaruoholajien tiheyteen vaikuttavia primaarisia tekijöitä vaan niiden indikaattoreita. Useinkaan näitä primaarisia tekijöitä ei tiedetä, ja niiden selvillesaamiseksi tarvitaan autekologista tutkimusta.

Syysvehnän rikkaruoholajistosta ja sen koostumuksesta tällainen tutkimus olisi tarvittu jo kemiallista torjuntaa aloitettaessa, ja tutkimus tulisi uusia esim. 20 vuoden välein, sillä lajikoostumus muuttuu nykyään nopeasti ja torjuntatulokset heikkenevät. Käytännön torjuntaa varten tulee olla selvillä rikkaruoholajiston koostumus torjunta-aikana, mutta rikkaruoholajien merkityksen selvittämiseksi tarvitaan myös biomassatiedot ja tiedot tärkeimpien lajien merkityksestä sadon alentajina. Kemiallinen torjunta tulee keskittää viljelyä haittaavaan rikkakasvilajistoon. Koska syysvehnän rikkakasvillisuus vaihtelee jonkin verran alueellisesti ja paikallisesti tulee selvittää rikkakasvillisuustyypit ja kunkin kasvillisuustyypin hävittämiseen parhaiten soveltuvat herbisidit ja niiden käyttöajat. 
Syysvehnälohkojen rikkaruohokoostumus poikkesi huomattavasti kevätviljojen rikkaruohokoostumuksesta (vrt. MUKULA et al. 1969). Syysrukiin rikkaruohokoostumus oli koko maan huomioonottaen melko erilainen, mutta Lounais-Suomessa syysrukiin rikkakasvikoostumus oli melko samanlainen kuin syysvehnän (M. RAATIKAINEN ja T. RAATIKAINEN 1979).

\section{Tiivistelmä}

Koko Suomen syysvehnäpelloista tutkittiin v. 1972-1974 otannalla $0.8 \%$. Tällöin todettiin, että syysvehnää viljeltiin yleensä suurilla tiloilla, vanhoilla pelloilla, savimailla, suurilla lohkoilla ja lähellä talouskeskusta. Syysvehnälohkoilla oli käytetty ennen syysvehnän viljelyä hyvin usein leikkuupuimuria ja herbisidejä. Esikasvina oli tavallisimmin syysvehnä tai muu vilja, vaikka neuvonta vastusti monokulttuuria. Peruslannoituksessa noudatettiin yleensä ohjeita, jopa ylitettiinkin suositellut käyttömäärät. Lajikesuosituksia yleensä noudatettiin ja uudet lajikkeet otettiin käyttöön muutamassa vuodessa. Kasvinsuojelu, varsinkin peittaus laiminlyötiin usein. Rikkaruohoruiskutuksissa olisi tullut käyttää useammin seosvalmisteita ja oikeata ruiskutusaikaa. Kylvösiemenmäärä oli usein ylisuuri ja kylvökausi liian pitkä, mistä aiheutui yksittäisillä tiloilla haittoja ja sadonmenetyksiä.

Valistuneimpien viljelijöiden tiloilla neuvontaa seurattiin ja noudatettiinkin melko nopeasti, mutta osa viljeli perinnäisiä tapojen noudattaen. Helppotajuinen neuvonta otettiin vastaan nopeammin kuin vaikeatajuinen. Neuvonnassa tulisi kiinnittää enemmän huomiota tilakohtaiseen neuvontaan.

Syysvehnälohkoilta tavattiin 130 rikkaruoholajia, joista 26 esiintyi yli 16 $\%$ :lla peltolohkoista. Rikkaruohoja oli keskimäärin 257 yksilöä tai versoa/ $\mathrm{m}^{2}$. Tiheimmässä kasvoivat syysyksivuotisista Viola arvensis, Matricaria spp., Stellaria media, Lapsana communis ja Myosotis arvensis, kevätyksivuotisista Galeopsis spp., Chenopodium album, Erysimum cheiranthoides, Polygonum aviculare, Myosurus minimus, Gnaphalium uliginosum ja Polygonum convolvulus, ja monivuotisista Agropyron repens. Rikkaruohokoostumus poikkesi ruispeltojen rikkaruohokoostumuksesta joten neuvonnan tulisi kohdistua viljelykasvikohtaiseen neuvontaan.

Rikkaruohojen tiheyteen vaikuttivat $\mathrm{mm}$. lohkon etäisyys talouskeskuksesta, lohkon ikä peltona, maalaji, maaperän kosteus, leikkuupuintikertojen määrä, herbisidikäsittelyjen määrä, esikasvi, kylvöaika, kasvukauden vaihe ja viljan peittävyys. Tekijät eivät aina vaikuttaneet suoranaisesti vaan olivat todellisten tekijöiden indikaattoreita.

Kiitokset. Tämän tutkimuksen kenttätyöt ja aineiston tietokonekäsittelyt on tehty pääosiltaan Maatalouden tutkimuskeskuksen Kasvinviljelyosaston tutkimusohjelman puitteissa ja Kasvinviljelyosaston rahoittamana. Parhaat kiitokset työtä monipuolisesti tukeneelle, käsikirjoituksen lukeneelle ja siihen arvokkaita korjauksia tehneelle prof. Jaakko Mukulalle, kenttätyön tekijöille, tietokonekäsittelyssä avustaneelle maist. Liisa Mattilalle, kokoomatyöhön osallistuneille ja käsikirjoituksen lukeneille ja siihen korjauksia tehneille prof. Pentti Teittiselle ja agr. Paavo Simojoelle. Kiitokset myös Suomen Akatemialle, joka myöntämällään apurahalla 
on merkittävästi tukenut työn toteuttamista erityisesti aineiston käsittelyvaiheessa ja käsikirjoituksen painokuntoon saattamisessa.

\section{Kirjallisuus}

AAMISEPP, A., STECKO, V. \& ÅBERG, E. 1967. Ogräsfröspridning vid bindarskörd och skördetröskning. Summary: Distribution of weed seeds at binder harvest and combining. Lantbr.högsk. Medd. 81: 1-31.

BORG, P. 1964. Über die Beziehungen der Ackerunkräuter zu einigen bodenökologischen Faktoren in der Landgemeinde Helsinki. Ann. Bot. Fenn. 1: 146-160.

BRUMMER, V., KESÄVAARA, H. \& ALITALO, O. 1971. Rikkakasvien levinneisyystutkimus 196970. Sv T-Tutkimusseloste. Sokerijuurikkaan viljelyn Tutkimuskeskuksen Tiedonantoja 1: 1-20.

DRAPER, N. R. \& SMITH, H. 1966. Applied regression analysis. 407 p. New York-London-Sydney.

ERVIÖ, L.-R. 1982. The emergence of weeds in the field. Ann. Agric. Fenn. 20: 292-303.

GRANSTRÖM, B. 1962. Studier över ogräs $i$ vårsådda grödor. Summary: Studies on weeds in spring sown crops. Stat. Jordbr. förs. Medd. 130: 1-188.

HAKKOLA, H. 1966. Syysviljojen kylvöaika Lounais-Suomessa. Koetoim. ja Käyt. $23: 32$.

HARVEY, W. R. 1966. Least-squares analysis of data with unequal subclass numbers. ARS 20-8, Agric. Res. Service, U.S. Dep. of Agric. 157 p.

HILLI, A. 1962. Rikkaruohot ja niiden torjunta. Maanviljelysoppi 2: 317-349.

HONKAVAARA, T. 1958. Syysviljojen kylvöaikakokeet Etelä-Pohjanmaan koeasemalla. Referat: Saatzeitversuche mit Wintergetreide in der Versuchstadion für Süd-Pohjanmaa. Maatal. ja Koetoim. 12: $177-187$.

JALAS, J. \& HONKALA, T. 1962. Über die Beziehung einiger Gartenunkräuter zum Nährstoffgehalt des Bodens in der Stadt Hämeenlinna in Südfinnland. Arch. Soc. Vanamo 16: 3-18.

- \& JUUSELA, T. 1959. Unkrautstudien und Bodenuntersuchungen auf den Grundwasserstauparzellen des Wasserwirtschaftlichen Versuchsfeldes Maasoja in Vihti, Südfinnland. Ann. Bot. Soc. Vanamo 30, 5: 1-61.

JAMALAINEN, E. A. 1962. Syysviljojen peittaus Suomessa. Summary: Trials on seed treatment of winter cereals in Finland. Ann. Agric. Fenn. 1: 175-191.

- 1964. Control of low-temperature parasitic fungi in winter cereals by fungicidal treatment of stands. Ann. Agric. Fenn. 3:1-54.

- 1966. Viljan siemenen peittaus. Maatalouden Tutkimuskeskus. Tietokortti 5 B 1: 1-2.

- 1969. Resistance of scandinavian winter cereal varieties to low temperature parasitic fungi. Ann. Agric. Fenn. 8: 251-263.

- \& LINNOMÄKI, H. 1966. Syysviljojen talvituhosienien kemiallinen torjunta. Maatalouden Tutkimuskeskus. Tietokortti 5 B 3: 1-2.

KAUHANEN, V. 1975. Iisalmen seudun viljapeltojen rikkakasvillisuudesta ja sitä säätelevistä tekijöistä. Summary: On weed vegetation in grainfields in Iisalmi region and the regulating factors. Savon Luonto 7: 45-50.

KÖYLIJÄRVI, J. 1971. Syysvehnälajikkeet Lounais-Suomen savimailla. Koetoim. ja Käyt. 28: 26.

- 1972. Syysviljojen typpi syys-, talvi- vai kevätlevityksenä. Koetoim. ja Käyt. 29: 38.

- 1974. Syysviljojen kylvö Lounais-Suomen oloissa. Koetoim. ja Käyt. 31: 25.

- 1975. Syysviljojen lannoitus, kylvö ja lajikkeet. Maatalouden Tutkimuskeskus. Lounais-Suomen Koeaseman Tiedote 3: 1-19.

- 1980a. Syysviljat viljatilojen tuoton varmentajina. Koetoim. ja Käyt. 1980: 26.

-1980b. Syysviljojen kylvöaika Etelä-Suomessa. Koetoim. ja Käyt. 1980: 30.

LAMPINEN, R. 1971. Kasvinviljely. Pelto-Pirkan Päiväntieto 1972: 76-81.

- 1976. Peltokasvien viljely. Viljakasvit. Kasvinviljelyoppi 2: 91-151.

LID, J. 1963. Norsk og svensk flora. 800 p. Oslo.

LINNOMÄKI, H. 1962. Syysviljojen talvituhosienien torjuntakokeita Hämeen koeasemalla. Koetoim. ja Käyt. 19: 3-4.

LÄHDE, V., HILLI, A. \& BREITENSTEIN, W. 1955. Rikkaruohojen kemiallinen torjunta. Kasvinsuoj.seuran Julk. 9: 1-36. 
MARJANEN, H. 1975. Syysviljojen talvehtimisesta paikalliskokeiden koetulosten valossa. Maatalouden Tutkimuskeskus. Paikalliskoetoimiston Tiedote 1: 1-31.

MARKKULA, M. 1973. Sales of pesticides in Finland 1972. Kemian Teollisuus 30: 360-361.

- 1974. Sales of pesticides in Finland in 1973. Kemia-Kemi 1: 625-628.

— \& TIITTANEN, K. 1975. Sales of pesticides in Finland in 1974. Kemia-Kemi 2: 377-378.

MATIKAINEN, P. \& PIETILÄINEN, L. 1966. Tuloksia rikkakasvihävitteiden käytöstä syysvehnällä. Koetoim. ja Käyt. 23: 34, 36.

MUKULA, J. 1964. Rikkaruohot ja niiden torjunta. 140 p. Helsinki.

- , RAATIKAINEN, M., LALLUKKA, R. \& RAATIKAINEN, T. 1969. Composition of weed flora in spring cereals in Finland. Ann. Agric. Fenn. 8: 59-110.

— \& RANTANEN, O. 1976. Syysvehnän viljely Suomessa 1950-1975. Maatalouden Tutkimuskeskus. Kasvinviljelylaitoksen Tiedote 3: 1-35.

— \& TEITTINEN, P. 1967. Uusia kokemuksia kemiallisesta laontorjunnasta. Koetoim. ja Käyt. 24: 13, 16.

PAATELA, J. 1953a. Peltonurmien perustamistavoista Suomessa. Summary: On cultural methods used at establishing rotation leys in Finland. Acta Agr. Fenn. 79, 1: 1-81.

- 1953b. Maamme heinänurmien botaanisesta koostumuksesta. Summary: On the botanical composition of the tame-hayfields in Finland. Acta Agr. Fenn. 79, 3: 1-128.

PESSI, Y. 1969. Typpilannoitteiden syyslevityksestä. Leipä Leveämmäksi 17, 4: 29-31.

- 1970. Väkilannoitteet ja niiden käyttö peltoviljelyssä. 214 p. Porvoo-Helsinki.

PETZOLDT, K. 1959. Wirkung des Mähdruschverfahren, auf die Verunkrautung. Z. Acker- u. Pfl.bau 109: 49-78.

RAATIKAINEN, M. 1970. Ympäristön pilaantuminen ja sen ehkäiseminen. Torjunta-aineet. SITRA:n julkaisusarja B, 2, V: 1-57.

— \& RAATIKAINEN, T. 1964. Kevätviljapeltojen ja niiden pientareiden kasveista Laihialla. Summary: Plant species growing on spring cereal fields and their edges at Laihia, Finland. J. Scient. Agric. Soc. Finl. 36: 135-160.

— \& RAATIKAINEN, T. 1971. Rikkakasvien runsauden muutoksista. Summary: Changes in abundance of weeds. Luonnon Tutkija 75: 153-159.

- \& RAATIKAINEN, T. 1972. Weed colonization of cultivated fields in Finland. Ann. Agric. Fenn. 11: $100-110$.

— \& RAATIKAINEN, T. 1975. Heinänurmien sato, kasvilajikoostumus ja sen muutokset. Summary: Yield, composition and dynamics of flora in grassland for hay in Finland. Ann. Agric. Fenn. 14: 57-191.

RAATIKAINEN, M. \& RAATIKAINEN, T. 1979. Syysrukiin perustaminen, hoito ja rikkaruohojen ekologia. Summary: Establishing and management of winter rye and the ecology of weeds in rye fields. J. Scient. Agric. Soc. Finl. 51: 432-479.

- , RAATIKAINEN, T. \& MUKULA, J. 1979. Weed species, frequencies and densities in winter cereals in Finland. Ann. Agric. Fenn. 17: 115-142.

— , RAATIKAINEN, T. \& TINNILÄ, A. 1971. Rikkakasvit ja niiden torjunta. Kasvinsuoj.seuran Julk. 46: 1-108.

SAARISALO-TAUBERT, A. 1963. Die Flora in ihrer Beziehung zur Siedlung und Siedlungsgeschichte in den südfinnischen Städten Porvoo, Loviisa und Hamina. Ann. Bot. Soc. Vanamo 35, 1: 1-190.

SAULI, J. O. (toim.) 1929. Maa ja Metsä I. Kasvituotanto 2: 361-798. Porvoo.

- 1943. Peltokasvinviljelys. Maamiehen Käsikirja 103-241. Helsinki.

SCHUBERT, R., HILBIG, G. \& MAHN, E.-G. 1975. Probleme der Agrogeobotanik. Wiss. Beitr. Martin-Luther-Univ. 1973/11 (P2): 1-213+1-16.

SIMOJOKI, P. 1972. Syysvehnän viljelytekniikka Keski-Suomessa. Koetoim. ja Käyt. 29: 41-42.

- 1980. Syysviljojen kylvöaika Keski-Suomessa. Koetoim. ja Käyt. 1980: 30.

SIMONEN, S. (toim.) 1944. Maatalouden Pikku Jättiläinen. 2. painos. 1212 p. Porvoo-Helsinki.

TALVITIE, H. \& KONSALA, J. 1971. Syysvehnälajikkeen savi- ja hietamaalla Tikkurilassa. Referat: Höstvetesorterna på ler- och mojord i Dickursby. Kehittyvä Maatalous 5. 3-11.

— \& LALLUKKA, U. 1973a. Syysvehnälajikkeet ja niiden laatu. Koetoim. ja Käyt. 30: 32.

— \& LALLUKKA, U. 1973b. Syyşvehnälajikkeet ja niiden laatu. Maatalouden Tutkimuskeskus. Tietokortti 2 B 14: 1-4.

— \& MARJANEN, H. 1972. Syysvehnä. Koetoim. ja Käyt. 29: 27-28. 
TIITTANEN, K. 1959. Kahukärpäsen viljakasveissa aiheuttamat tuhot Suomessa vuosina 1948-1958. Referat: Schäden durch die Fritfliege (Oscinella frit. L., Dipt.) bei Getreide in Finnland in den Jahren 1948-1958. Publ. Finn. State Agric. Res. Board 178: 110-125.

WALLE, O. 1929. Nurmikasvit. Maa ja Metsä I. Kasvintuotanto II: 747-798.

VALLE, O. 1958. Kylvöajan merkityksestä syysrukiin ja syysvehnän viljelyssä Etelä-Suomessa. Summary: The influence of sowing time on the cultivation of winter rye and winter wheat in South Finland. Maatal. ja Koetoim. 12: 159-176.

- 1962. Viljakasvien viljely. Maanviljelysoppi 2: 91-144. Porvoo-Helsinki.

VANHANEN, R. 1981. Syysviljojen peittaus. Koetoim. ja Käyt. 1981: 35.

YLIMÄKI, A. 1975. Kasvitaudit ongelmana erikoistuvassa viljantuotannossa. Referat: Växtsjukdomarna problem i specialiserad spannmålsodling. Kehittyvä Maatalous 24: 11-20.

YLLÖ, L. 1969. Syysrukiin ja syysvehnän kylvöaikakokeet kasvinviljelylaitoksella 1958 (1927)-1967. Summary: Sowing date trials with winter rye and winter wheat at the Department of Plant Husbandry, 1958 (1927)-1967. Ann. Agric. Fenn. 8: 184-192.

Ms received May 11, 1983 